\title{
Compartmentalized Signaling in Aging and Neurodegeneration
}

\author{
Giulietta Di Benedetto 1,2,*, Liliana F. Iannucci ${ }^{2,3}$ (), Nicoletta C. Surdo ${ }^{1,2}$, Sofia Zanin ${ }^{2,3}$, Filippo Conca ${ }^{2,4} \mathbb{D}^{\text {, }}$ \\ Francesca Grisan ${ }^{2,4}$, Andrea Gerbino ${ }^{-(D)}$ and Konstantinos Lefkimmiatis $2,3, *(\mathbb{D})$ \\ 1 Neuroscience Institute, National Research Council of Italy (CNR), 35121 Padova, Italy; \\ nicolettaconcetta.surdo@cnr.it \\ 2 Veneto Institute of Molecular Medicine, Foundation for Advanced Biomedical Research, 35129 Padova, Italy; \\ lilianafelicia.iannucci@unipv.it (L.F.I.); sofia.zanin@unipv.it (S.Z.); filippo.conca@studenti.unipd.it (F.C.); \\ francesca.grisan@gmail.com (F.G.) \\ 3 Department of Molecular Medicine, University of Pavia, 27100 Pavia, Italy \\ 4 Department of Biology, University of Padova, 35122 Padova, Italy \\ 5 Department of Biosciences, Biotechnology and Biopharmaceutics, University of Bari, 70121 Bari, Italy; \\ andrea.gerbino@uniba.it \\ * Correspondence: giulietta.dibenedetto@cnr.it (G.D.B.); konstantinos.lefkimmiatis@unipv.it (K.L.)
}

check for updates

Citation: Di Benedetto, G.;

Iannucci, L.F.; Surdo, N.C.; Zanin, S.;

Conca, F.; Grisan, F.; Gerbino, A.;

Lefkimmiatis, K. Compartmentalized

Signaling in Aging and

Neurodegeneration. Cells 2021, 10,

464. https://doi.org/10.3390/

cells10020464

Academic Editors: Paola Pizzo and Riccardo Filadi

Received: 30 December 2020

Accepted: 17 February 2021

Published: 22 February 2021

Publisher's Note: MDPI stays neutral with regard to jurisdictional claims in published maps and institutional affiliations.

\begin{abstract}
The cyclic AMP (cAMP) signalling cascade is necessary for cell homeostasis and plays important roles in many processes. This is particularly relevant during ageing and age-related diseases, where drastic changes, generally decreases, in cAMP levels have been associated with the progressive decline in overall cell function and, eventually, the loss of cellular integrity. The functional relevance of reduced cAMP is clearly supported by the finding that increases in cAMP levels can reverse some of the effects of ageing. Nevertheless, despite these observations, the molecular mechanisms underlying the dysregulation of cAMP signalling in ageing are not well understood. Compartmentalization is widely accepted as the modality through which cAMP achieves its functional specificity; therefore, it is important to understand whether and how this mechanism is affected during ageing and to define which is its contribution to this process. Several animal models demonstrate the importance of specific cAMP signalling components in ageing, however, how age-related changes in each of these elements affect the compartmentalization of the cAMP pathway is largely unknown. In this review, we explore the connection of single components of the cAMP signalling cascade to ageing and age-related diseases whilst elaborating the literature in the context of cAMP signalling compartmentalization.
\end{abstract}

Keywords: aging; neurodegeneration; compartmentalization; cAMP; PKA

\section{Introduction}

The overarching mechanism that allows coupling extracellular cues to specific cellular functions through the cAMP/PKA (Protein Kinase A) axis is compartmentalization, i.e., the strict spatiotemporal organization of every step of the cAMP/PKA cascade. For instance, the link between G-protein coupled receptors (GPCRs) and adenylyl cyclases (ACs) can be strictly confined [1], ensuring that messenger is generated only in specific submembrane compartments. Following production, the diffusion and subcellular distribution of cAMP are shaped by the actions of phosphodiesterases (PDEs) [2]. Indeed, these enzymes can determine the levels cAMP can reach in specific sites and consequently the subsets of PKA (and eventually other effectors) to be activated. The inhomogeneous subcellular distribution of PKA is determined by a family of proteins called A kinase anchoring proteins (AKAPs) [3] that tether this enzyme in specific cellular locations maximizing the probability that active PKA phosphorylates a select subset of local targets. PDEs contribute also to the final step of the cascade (termination) by quickly bringing cAMP to its basal levels after its production has ended, while the phosphatases, which dephosphorylate PKA targets in a non-uniform pattern, are the enzymes that terminate the effects of PKA and contribute 
both to the spatial distribution and duration of its signals [4,5]. The players participating in the compartmentalization machinery of the cAMP/PKA axis are illustrated in Figure 1.

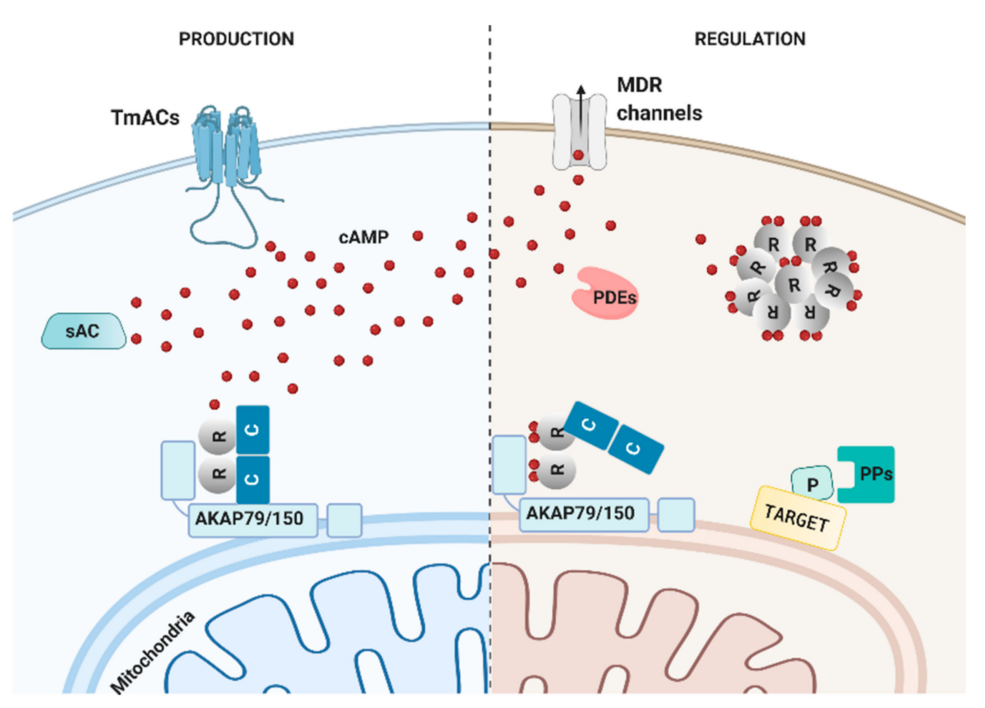

Figure 1. Compartmentalization mechanisms of the cAMP/PKA axis. Cyclic AMP can be produced at the plasma membrane by transmembrane adenylyl cyclases (tmACs) or intracellularly, by the soluble adenylyl cyclase (sAC). Once produced, the levels of cAMP are regulated by 3 main mechanisms: degradation by phosphodiesterases (PDEs), extrusion from the cells to the extracellular milieu by multi drug resistance channels (MDR channels) or buffering by RI alpha-constituted membraneless organelles. A final, cAMP-independent, regulatory step is exerted by the action of phosphatases (PPs) that by dephosphorylating PKA-phosphorylated targets effectively terminate the cascade. Created with BioRender.com.

Ageing affects to some extent all tissues and organs; however, the brain seems to be particularly vulnerable to this process. In the ageing brain synaptic function gradually decreases, leading to the deterioration of synaptic plasticity, which is a crucial event in the onset of neurodegenerative disorders (NDs). Age-related NDs represent a true emergency as they affect a large part of elderly population, impinging on patient frailty and cognition, with devastating consequences for affected individuals and their caretakers [6]. Indeed, NDs are characterised by progressive loss of specific neuronal populations, preceded by deficits in their synaptic functions and often leading to some level of dementia. The insurgence of cognitive dysfunction has been observed also in diseases in which the most prominent effects are motor deficits such as Huntington's and Parkinson's diseases $[7,8]$.

During the last two decades it emerged that alterations of the cAMP/PKA signalling axis in specific brain regions could contribute to the onset of dementia-related pathologies [9]. An essential cognitive function, that is affected early in neurodegeneration, is memory. Memory relies on the capacity of neuronal networks to tune the strength of connecting synapses (synaptic plasticity), a process largely regulated by PKA. In addition, this kinase has a fundamental role in synaptic maintenance and memory consolidation, by regulating transcription through its target cAMP Response Element Binding protein (CREB) [10]. Despite the documented importance of PKA in several neuronal and cognitive processes, the connection between compartmentalization of the cAMP/PKA signalling axis and NDs is not consolidated. In this manuscript we discuss the connection between alterations of cAMP compartmentalization and the most common NDs.

Parkinson's Disease (PD) can be familial (10\% of cases), or sporadic, in which age is the central risk factor. It is a long-term ND, characterized by alterations in the morphology of the striatum in the basal ganglia, the brain region involved in movement control, associative learning, planning, working memory, and emotion [11]. Functionally, PD patients display motor and cognitive impairments that depend on the progressive degeneration of 
dopaminergic neurons within the substantia nigra pars compacta [12,13], that project to the striatum forming the nigrostriatal pathway, which helps to stimulate the cerebral cortex and initiate movement [13]. The dopaminergic depletion in PD leads to the dysfunction of medium spiny neurons (MSNs) in the striatum [14], and the appearance of the characteristic motor symptoms $[15,16]$.

Alzheimer's Disease (AD), the most frequent cause of dementia in Western societies, is an age-related disease characterized by cognitive impairment and progressive memory loss, due to massive degeneration of the association cortices [9,12,17-19]. With the exception of a small number of familiar mutations, the etiology of the disease remains unclear [12,20]. AD belongs to NDs called tauopathies, characterized by the deposition of abnormal Tau protein in the brain [21]. In the case of AD, Tau becomes hyperphosphorylated and unable to bind the microtubules, and begins to aggregate forming intracellular fibrils (also known as neurofibrillary tangles, NFTs) both in neurons [22] and astrocytes [23]. In neurons, microtubules are destabilized and collapse, disabling intracellular transport [24,25]. Post-mortem human AD brains are characterized by NFTs, and extracellular aggregates of A $\beta 1-42$, the proteolytic product of amyloid precursor protein (APP), called amyloid plaques $[12,19,26-28]$. The overproduction of $A \beta 1-42$ initially results in the formation of toxic $A \beta$ oligomers that gradually develop in amyloid plaques. The progressive accumulation of $A \beta$ oligomers [29] and/or NFTs [30] can lead to synapse elimination, disrupt neuronal function and ultimately lead to neuronal death. AD neurons present alterations in the function of the major cellular organelles, including endoplasmic reticulum (ER) [31], lysosomes [32], and especially mitochondria [18].

The connection of mitochondria to age-related diseases, particularly the neurodegenerative ones, is unequivocal [33-35], owing to their obvious role in providing neurons with the energy necessary to perform vital functions [36-38]. However, the importance of mitochondrial distribution and dynamics for proper neuronal function is becoming established [39-42]. Mitochondria are highly dynamic and undergo continue cycles of fusion and fission, that are important for their metabolic activity but also for their transportation to or from synapses [43,44]. In recent years, therefore, it has become clear how perturbations in mitochondrial dynamics contribute to the aetiology of NDs [45], including $\mathrm{AD}$ [46] and PD [47].

In the following chapters we will discuss the involvement of cAMP/PKA signalling in the molecular mechanisms underlying different age-related pathologies from a perspective of compartmentalization.

\section{Key Players}

\subsection{Adenylyl Cyclases (ACs)}

ACs, the enzymes responsible for cAMP production, are key elements in shaping cAMP signalling, both in time and space [48-50]. ACs are classified into six classes (I-VI), with all eukaryotic members belonging to class III [51,52]. The mammalian ACs comprise one soluble (sAC), stimulated by bicarbonate, calcium $\left(\mathrm{Ca}^{2+}\right)$ and ATP [53,54], and nine transmembrane enzymes (tmAC1 to tmAC9), activated by $\mathrm{G} \alpha$ s proteins following activation of G-protein coupled receptors (GPCRs). Each isoform displays distinct tissue-specific expression patterns as well as differential subcellular localization $[48,50,51,55,56]$. These characteristics, together with selective regulatory mechanisms for each AC [48], confer to these enzymes a key role in the compartmentalization of the cAMP signalling cascade.

\subsection{Phosphodiesterases (PDEs)}

While ACs are responsible for cAMP production, another family of enzymes, the PDEs are responsible for its degradation and the reestablishment of its basal levels [57] after AC-dependent production subsides [57-59]. Nevertheless, the simple balance between production and degradation per se cannot fully account for the onset and maintenance of the compartmentalization essential to the wide range of cellular functions regulated by the cAMP signalling pathway [59]. In fact, cAMP elevations are transduced into different 
effects according to the spatiotemporal activation of its effectors (i.e., PKA or exchange protein activated by cAMP (EPAC)), an event that depends on the coordination of several players (PDEs, AKAPs and phosphatases). PDEs play a crucial role in this process [57,60], contributing to the spatial distribution of cAMP [61,62]. In the human genome, 22 different genes encode for 11 PDE families [63-65]. Each family collects enzymes that share similar kinetic features, regulatory pathways, localization and structure $[65,66]$. From a functional point of view, the more than $100 \mathrm{PDE}$ variants can be subdivided in three groups: those able to hydrolyze both cAMP and $3^{\prime}, 5^{\prime}$-cyclic guanosine monophosphate (cGMP) (i.e., PDE1, 2, 3, 10 and 11), only cAMP (i.e., PDE4, 7 and 8), or selectively cGMP (i.e., PDE5, 6 and 9) $[12,61,67]$. Since 1982, when the hypothesis of the compartmentalization of the cAMP signalling was first proposed [68], numerous investigations suggested a model in which cAMP availability near PKA holoenzymes is defined by the actions of PDEs that restrict the messenger in microdomains [67]. Importantly, in a recent report, Bock and colleagues added a significant piece of information in the understanding of PDE-dependent formation of cAMP microdomains [69]. Using a cell permeable fluorescent cAMP analogue (8FDA-cAMP), in combination with FRET-based biosensors [5,70] and a number tools that combined PDEs to molecular rulers, they were able to determine the area to which PDEs can influence cAMP levels, generating microdomains. They concluded that PDEs can determine nanodomains characterized by low cAMP concentration, thus preventing PKA activity in the close proximity of PDEs itself [69]. Interestingly, in a concomitant manuscript, Zhang and colleagues found that the PKA regulatory subunit I $\alpha$ (PKA-RI $\alpha$ ) can undergo a liquidliquid phase separation generating membraneless organelles capable of entrapping cAMP and acting as regulators of its availability and consequently compartmentalization [71]. These two findings suggest that cAMP buffering together with PDE activity are the major determinants of resting cAMP levels and likely shape its signals upon production.

\subsection{Protein Kinase A (PKA)}

The most studied effector of cAMP is PKA, a tetrameric enzyme composed by two catalytic $(C)$ and two regulatory (R) subunits. In mammals, three types of $C$ subunits $(C \alpha, C \beta$ and $C \gamma)$, and four variants of $R$ subunits $(R I \alpha, R I \beta, R I L$ and $R I I \beta)$ have been described [72]. In the inactive PKA tetramer, two $C$ subunits are associated and inhibited by two $\mathrm{R}$ subunits. Each $\mathrm{R}$ subunit binds two cAMP molecules and dissociates from the $C$ subunits, that are then free to phosphorylate a wide number of targets. While cAMP has a number of effector proteins, it is broadly accepted that PKA-dependent phosphorylation is one of the main factors to contribute to the characteristic pleiotropy of the cAMP cascade. In order for PKA to phosphorylate its vast array of targets [73] with high spatiotemporal specificity, cells developed a sophisticated compartmentalization mechanism, involving ACs, PDEs, AKAPs and phosphatases, ensuring the control of this kinase. The complexity of the cAMP/PKA axis thus allows the cell to control and coordinate a plethora of functions through a relatively linear pathway. However, the maintenance of this delicate but necessary equilibrium is not error proof and can deteriorate during natural ageing. Indeed, dysregulation of PKA activity is increasingly recognized as a causal factor in the development of neurodegenerative and other age-related diseases [74].

Mature neurons rely on mitochondria both for energy [75] and $\mathrm{Ca}^{2+}$ buffering [76]; it is not surprising therefore that mitochondrial dysfunction is a common feature of neurological and neurodegenerative disorders. PKA participates in the control of several mitochondrial processes, including mitochondrial dynamics, trafficking and quality control, and high PKA activity promotes mitochondrial fitness, ultimately resulting in neuroprotection. PKA activity is not uniformly distributed throughout the mitochondria [77,78]. Acting at the outer mitochondrial membrane (OMM), PKA hinders apoptosis, through direct phosphorylation and inactivation of the pro-apoptotic protein BAD $[79,80]$. In addition, PKA-dependent phosphorylation of the mitochondrial $\mathrm{Na}^{+} / \mathrm{Ca}^{2+}$ exchanger isoform 3 (NCX3) facilitates the efflux of mitochondrial $\mathrm{Ca}^{2+}$, improving cell survival during hypoxic stress or during $\mathrm{Ca}^{2+}$ overload, both conditions to which neurons are particularly 
vulnerable [81]. Damaged mitochondria are eliminated through mitophagy, a central quality control mechanism whose dysregulation is involved in ageing [82] but also in NDs, including Parkinson's [83], Huntington [84], and Alzheimer's [85] diseases. Efficient mitophagy relies on mitochondrial dynamics, as mitochondrial fission and fusion events can facilitate or hinder mitophagy, respectively [86]. PKA activity promotes mitochondrial elongation by inhibiting Dynamin related protein 1 (Drp1), a master regulator of mitochondrial fission [87]. This mechanism is particularly important in neurons, where increased PKA-dependent Drp1 phosphorylation was shown to be neuroprotective both in vitro [88,89] and in vivo [90]. Interestingly, PKA is also involved in the protection of depolarized neuronal mitochondria during axonal retrograde transport [91]. In this case PKA phosphorylates proteins of the MICOS complex destabilizing PTEN-induced kinase 1 (PINK1), which prevents the recruitment of Parkin and thus mitophagy [92]. Noteworthy, PKA activity was shown to tune the machinery responsible for mitochondrial trafficking in neurons. Indeed, PKA-dependent phosphorylation of NED1 inhibited retrograde mitochondrial movement [93], while PKA, in synergy with PINK1, were shown to act on Miro to enhance anterograde trafficking and dendrite length [94].

\subsection{A Kinase Anchoring Proteins (AKAPs)}

AKAPs constitute a family of more than 50 distinct scaffolding proteins defined by their common ability to complex with the PKA R subunits [95] as well as other regulatory elements of the cAMP cascade such as phosphatases and PDEs. Targeting of AKAPs to specific subcellular domains is essential for the generation of local cAMP/PKA functional units called microdomains [96,97].

AKAP1 (also known as D-AKAP1, AKAP121, AKAP149 and AKAP84) localizes at the OMM, and contains multiple interaction domains that allow it to complex with both PKA RI and RII subunits [98] but also to complex with phosphatases and mRNAs [99] and optimally be the platform for the generation of a cAMP/PKA signalling microdomain. AKAP1 has been implicated in the control of mitochondrial dynamics and cell death [99,100]. In addition, AKAP1 is involved in neuronal development [101], as demonstrated by experiments in cultured hippocampal neurons, where increasing AKAP1 levels increased dendritic outgrowth and reduced the number of synapses [102]. AKAP1 tethers at the OMM both PKA and the opposing phosphatases PP1 and Calcineurin (CaN) [103], coordinating mitochondrial fission/fusion through the regulation of the Drp1 phosphorylation extent. Specifically, PKA-dependent phosphorylation of Ser637 inhibits Drp1 and prevents fission, which results in elongated mitochondria [78,104]. On the other hand, CaN dephosphorylates Drp1, opposing the actions of PKA and promoting mitochondrial fragmentation [105].

Among the AKAPs involved in the regulation of neuronal function, AKAP79/150 (human79/rodent150; also known as AKAP5) plays a pivotal role in synaptic strength. This protein acts as a molecular platform, allowing the formation of complexes controlling the phosphorylation state of postsynaptic glutamate AMPARs and L-type voltage-gated $\mathrm{Ca}^{2+}$ channels (LTCCs) [74,106-109]. AKAP79/150-based complexes situated in the proximity of these receptors can affect both LTP and LTD, and the strength of individual synapses [110-112]. AKAP79/150 is essential in coordinating the antagonistic actions of PKA and CaN that regulate AMPAR levels within the post synaptic density (PSD). Specifically, phosphorylation of the AMPAR subunit GluR1 at S845 fosters its postsynaptic accumulation during the initial phase of LTP [107], whereas its dephosphorylation results in increased AMPAR endocytosis during LTD [113-115]. AKAP79/150 is targeted to the PSD via direct interaction with the plasma membrane [116] or by binding to N-cadherin [117] and F-actin [118]. Within the PSD, AKAP79/150 is dynamically connected to NMDARs and AMPARs by the scaffolding proteins PSD-95 and SAP97, respectively $[119,120]$. Thanks to its connection to these scaffolds, AKAP79/150 has also a structural function within the PSD. Indeed, it participates in the regulation of the synaptic size and strength, which ultimately underlie cognitive process [121]. 


\subsection{Calcium $\left(\mathrm{Ca}^{2+}\right)$ Compartmentalization}

Cyclic AMP is not the only second messenger to achieve functional pleiotropy through compartmentalization. For this reason, we will also provide a concise overview of the role that compartmentalization of the other major second messenger, $\mathrm{Ca}^{2+}$, may have in ageing and age-related NDs. Under physiological conditions, cytosolic $\mathrm{Ca}^{2+}$ levels are maintained to nanomolar levels by the concerted activity of $\mathrm{Ca}^{2+}$ transporters located at the plasma membrane (PM) and the $\mathrm{Ca}^{2+}$-storing organelles, the main of which is the endoplas$\mathrm{mic} /$ sarcoplasmic reticulum (ER/SR); nevertheless, other organelles such as mitochondria [122], Golgi apparatus [123], endosomes and lysosomes [124] actively participate in shaping $\mathrm{Ca}^{2+}$ signals. Changes in the concentration patterns of $\mathrm{Ca}^{2+}$ are rapidly sensed by the cell and decoded to finely regulate a wide range of physiological events, such as release of neurotransmitters, cellular proliferation, muscle contraction and regulation of cell death [125].

\subsection{Alterations of cAMP Compartmentalization in Aging}

2.6.1. ACs

The correlation between ACs and ageing was firstly demonstrated in the heart, where AC5 and AC6 are major players in the sympathetic regulation of cardiac function [50,52]. In addition, other $\mathrm{AC}$ isoforms such as $\mathrm{AC} 8$ have been linked to age-dependent myocardial dysfunction and age-dependent cardiac remodeling [126]. Stimulation of beta-adrenergic receptors ( $\beta$-ARs) results in increased heart rate, contractility, and blood pressure. A common consequence of ageing is the decline in heart function, which is usually associated with altered $\beta$-AR signalling [127]. Notably, the age-related functional and structural changes, which include increased cardiomyocyte size and myocardial thickness [128], resemble those observed in heart failure (HF) [129]. At the molecular level, the observed reduction of $\beta$-AR density [130] and decreased $\beta$-AR responsiveness could be explained by disturbances of the cAMP/PKA pathway compartmentalization, which result from altered $\beta$-AR/AC coupling [131-134]. Interestingly, both in ageing and chronic conditions such as HF, the decrease in cardiac outcome is compensated by increased sympathetic activity, that, however, can eventually lead to cardiac remodeling and increased cardiomyocyte apoptosis with adverse patient outcomes [135-137]. Notably, $\beta$-AR antagonists have protective effects on patients of HF with decreased ejection fraction (EF) but not, paradoxically, on those with preserved EF [138]. Taken together, these data showcase the complexity of $\beta$-AR signalling and its pharmacological targeting, and the need for alternative therapeutic strategies targeting different components of the signalling cascade, as, for example, ACs.

Animal studies have suggested that, during ageing, the lack of AC5 is advantageous in several respects. AC5 is a major regulator of cardiac inotropy and chronotropy, however it could also have adverse effects for the heart. In fact, in mouse models, cardiac-specific overexpression of AC5 enhanced basal cardiac performance [139], but also decreased the cardiac resistance to prolonged stress [140]. The adverse effects of AC5 overexpression are attributed to a pathway that involves the SIRT1/FoxO3a axis [141]. Indeed, in AC5 overexpression models, prolonged catecholamine stress results in SIRT1 and FoxO3a inhibition that in turn decrease MnSOD transcription resulting in severe cardiomyopathy (Figure 2 left panel). Conversely, AC5 disruption protects the heart from the cardiomyopathy induced by chronic pressure overload and catecholamine stress, and leads to better exercise performance [142-146], most likely due to preserved SIRT1 and FoxO3 activity and MnSOD levels [140]. In addition, proteomic analysis in mice lacking AC5, which show increased lifespan and stress resistance, evidenced significant activation of the Raf/MEK/ERK signalling cascade, which in turn upregulated MnSOD levels during ageing [145] (Figure 2 right panel). MnSOD protects from oxidative stress and promotes longevity and its upregulation could account for the $30 \%$ lifespan increase in AC5 KO compared to wild type (wt) [145]. Interestingly, this appears to be a common mechanism among longevity models, including the one due to caloric restriction. Indeed, both these models have similar gene regulation in various tissues, and they are protected from age-dependent cardiomyopathy 
as well as diabetes and obesity [147]. Ageing AC5 KO mice are protected also against osteoporosis, and display improved exercise capacity [142]. From a mechanistic point of view, AC5 deletion, in addition to offering protection from oxidative stress, appears to mimic the effects of exercise training by up-regulating the SIRT1/PGC- $1 \alpha$ pathway and nitric oxide signalling [148]. Untrained AC5 KO animals present lower levels of sympathetic tone compared to wt animals, however they show better exercise capacity [148]. Moreover, ageing is a risk factor for spontaneous onset of cancers as suggested by the finding that AC5 KO animals had lower incidence of common age-related neoplasms, were protected from mammary tumor development and displayed decreased melanoma growth. These studies were further corroborated by independent investigations on the use of an FDA approved pharmacological inhibitor of AC5 as a possible pharmacological approach for cancer treatment and prevention [149]. All together these beneficial effects suggest that lack of AC5 promotes healthy ageing, most likely regulating the ability of the cells to cope with oxidative stress [140].

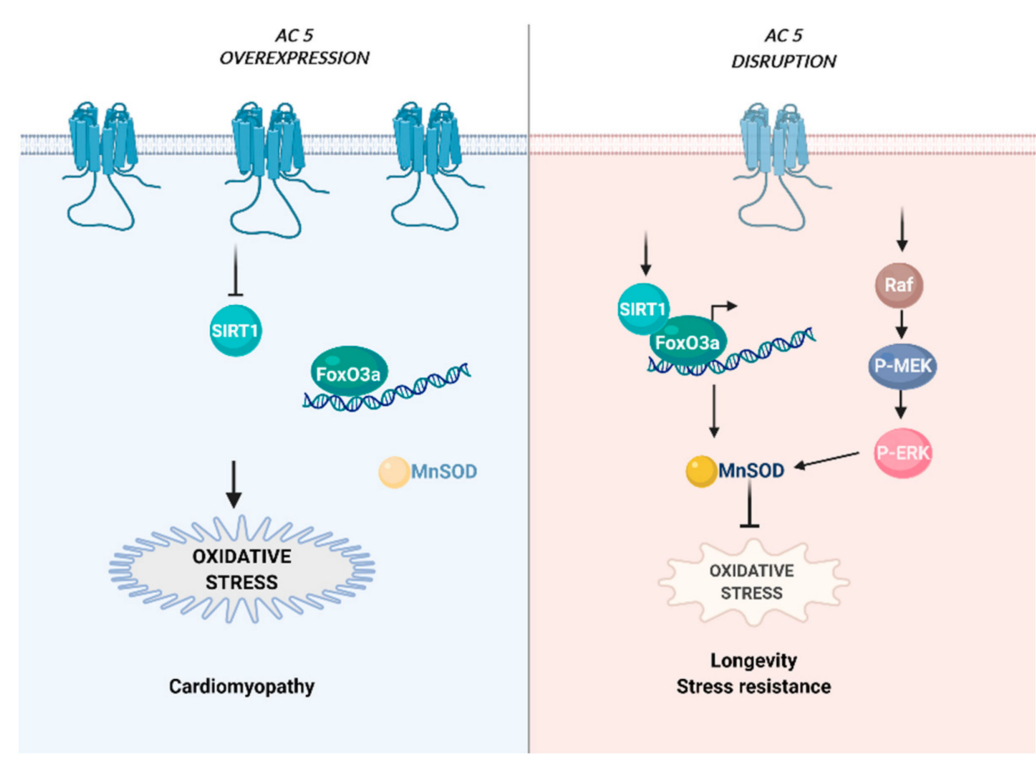

Figure 2. Schematic representation of the main AC5-driven pathways in ageing. (left panel): AC5 overexpression leads to enhanced oxidative stress through the SIRT1/FoxO3a axis. Conversely, disruption of AC5 leads to beneficial effects through the SIRT1/FoxO3 activity and the Raf/MEK/ERK signalling cascade, both impinging on the MnSOD levels (right panel). Created with BioRender.com.

An additional major cardiac AC isoform is AC6. While AC5 and AC6 share high sequence similarity (up to $65 \%$ ) and are both inhibited by sub-micromolar concentrations of $\mathrm{Ca}^{2+}$, they display no functional overlap $[150,151]$. In fact, AC6 inhibition or ablation produces none of the beneficial phenotypes observed in AC5 KO animals. On the contrary, depletion of AC6 impairs cAMP production and $\mathrm{Ca}^{2+}$ handling, which lead to decreased Left Ventricular (LV) function that, interestingly, is more severe in males [152,153]. Cardiac overexpression of AC6 improves the function of ageing hearts [152] and shows beneficial effects in cardiomyopathy, myocardial infarction and HF [154-156]. In line with these findings, increased AC6 expression in the hearts of mice with severe congestive HF improved LV systolic and diastolic function and reduced cardiomyocyte apoptosis [157]; it did not protect, however, from chronic pressure overload [158]. The precise molecular mechanisms underlying the differences between the functional outcomes of AC5 and AC6 remain to be established; however, given their high similarity, it is tempting to speculate that their subcellular distribution may be the determining factor. In fact, AC6 was proposed to localize in non-caveolin fractions while AC5 was found principally in caveolin-rich fractions in vascular smooth muscle cells [159]. However, whether this differential localization is functionally significant remains to be established. 
A recent study linked AC3 mutations to age-related increase in adiposity. In fact, AC3 KO mice develop age-dependent obesity, and recessive mutations in the human gene encoding AC3 were identified in two families with severe obesity. These data suggest a crucial involvement of AC3 in the control of age-dependent weight regulation, pointing to this enzyme as a promising pharmacological target [160].

In the ageing brain, synaptic function gradually deteriorates, causing the decline of synaptic plasticity and consequent memory impairment. In ageing brains and associated diseases, a marked decrease in the cAMP levels (with specific exceptions in prefrontal cortex and in hippocampus of brains affected by Huntington's Disease (HD)) is frequently observed [9,161-163]. Lower cAMP levels could signify decreased production or increased degradation of the messenger, therefore the assessment of AC and PDE levels and activity is crucial for understanding the signalling events and their role in ageing and associated diseases.

In humans, a reduction in AC activity was observed both in ageing and diseased brains $[9,164-166]$. Animal studies corroborated these findings to a good extent, consistently reporting a reduction in the basal or stimulated levels of cAMP during ageing $[163,167-170]$. Activation of the cAMP/PKA axis by $\mathrm{Ca}^{2+}$ is a key pathway for synaptic plasticity and memory $[171,172]$, and, during ageing, the crosstalk between $\mathrm{Ca}^{2+}$ and cAMP can be less effective, resulting in decreased $\mathrm{Ca}^{2+}$-stimulated ACs activation (especially in the hippocampus) with grave consequences [173]. $\mathrm{AC} 1$ and $\mathrm{AC} 8$ are the major $\mathrm{Ca}^{2+}$ stimulated ACs in the brain. Increasing the expression of AC1 (AC1 Tg mice) selectively enhanced recognition memory in young mice without any effect on fear or spatial memory. Surprisingly, aged AC1 Tg mice had poorer spatial memory compared to aged-matched wt controls [173]. Based on these findings it was proposed that the age-dependent decrease in $\mathrm{Ca}^{2+}$-stimulated ACs activity may be an adaptive mechanism to maintain spatial memory formation [173]. Interestingly, this hypothesis was also supported by studies showing that $\mathrm{Ca}^{2+} / \mathrm{CaM}$-sensitive ACs likely contribute to long-term memory formation in humans and by postmortem studies on Alzheimer's brains finding that AC1 levels were significantly decreased [174].

\subsubsection{PDEs}

The reported levels of PDEs during ageing are not uniform, often region-specific and sometimes contradictory [9]. For instance, during ageing, an increase in PDE expression is detected in hippocampus, whereas a decrease is observed in the cortex. In the striatum and cerebellum the situation is even more variable, with PDE levels increasing or decreasing depending on the isoform type. In regards of activity (which sometimes is decoupled from the absolute expression levels), in hippocampus, cortex, striatum, and cerebellum the overall PDE activity increases with ageing [9].

Given the broad spectrum of diseases that present altered PDE levels and/or activity, PDEs became the focus of therapeutic endeavors targeting ageing-related disorders. However, despite the interest in PDEs as drug targets, the possible changes in the expression of PDE isoforms across the lifespan is poorly characterized. A unique comprehensive study on region-specific (17 PDE isoforms in 4 brain regions) and age-related PDE expression patterns [175] revealed that patterns in rodents are largely consistent with those in humans and that a select minority of PDE isoforms exhibit brain region-specific changes in expression from early to late adulthood. The most robust age-related changes in PDE mRNA and protein expression were increased PDE11A and PDE8A in hippocampus and PDE8A and PDE1C in the striatum. Of interest, PDE11A and PDE8A display particularly enriched expression in the brain versus the periphery. These age-related changes in PDE expression may reflect an attempt to restore the balance of cyclic nucleotide signaling in ageing [175]. On the other hand, dysregulation of the cAMP/PKA pathway in ageing can also be due to mis-compartmentalization of PDEs and their consequent reduction in dendrites [176,177]. Indeed, PDE inhibition phenocopies or exacerbates neuronal ageing in young or old monkeys respectively $[177,178]$. 


\subsubsection{PKA}

Under normal non-pathologic conditions, the role of PKA compartmentalization in the brain is showcased by its involvement in synaptic plasticity. This process depends on the activity of N-methyl-D-aspartate (NMDA) receptors and $\alpha$-amino-3-hydroxy-5-methyl4-isoxazolepropionic acid (AMPA) receptors, both for strengthening (through long term potentiation, LTP) and weakening (through long term depression, LTD) synaptic efficiency. PKA is directly involved in these processes as it regulates both the number and biophysical status of AMPA receptors (AMPARs) in the PSD regions [179] (see Figure 3). In addition to synaptic plasticity, PKA impinges on synaptic maintenance and memory consolidation through its target CREB that plays a fundamental role in the conversion of short-term to long-term memory [10]. Upon PKA-dependent phosphorylation at S133, CREB assembles with its cofactors in a multiproteic complex at the level of CRE sequences in the promoters of genes involved in synaptic plasticity, regulating their transcription [180,181]. In addition, CREB can affect memory and other cognitive processes indirectly, by regulating adult hippocampal neurogenesis [182]. The role of the PKA/CREB axis in the nervous system is further testified by increasing evidence connecting changes in this pathway to deficits in brain function typical of ageing and age-related diseases, both in human patients and in animal models [183].

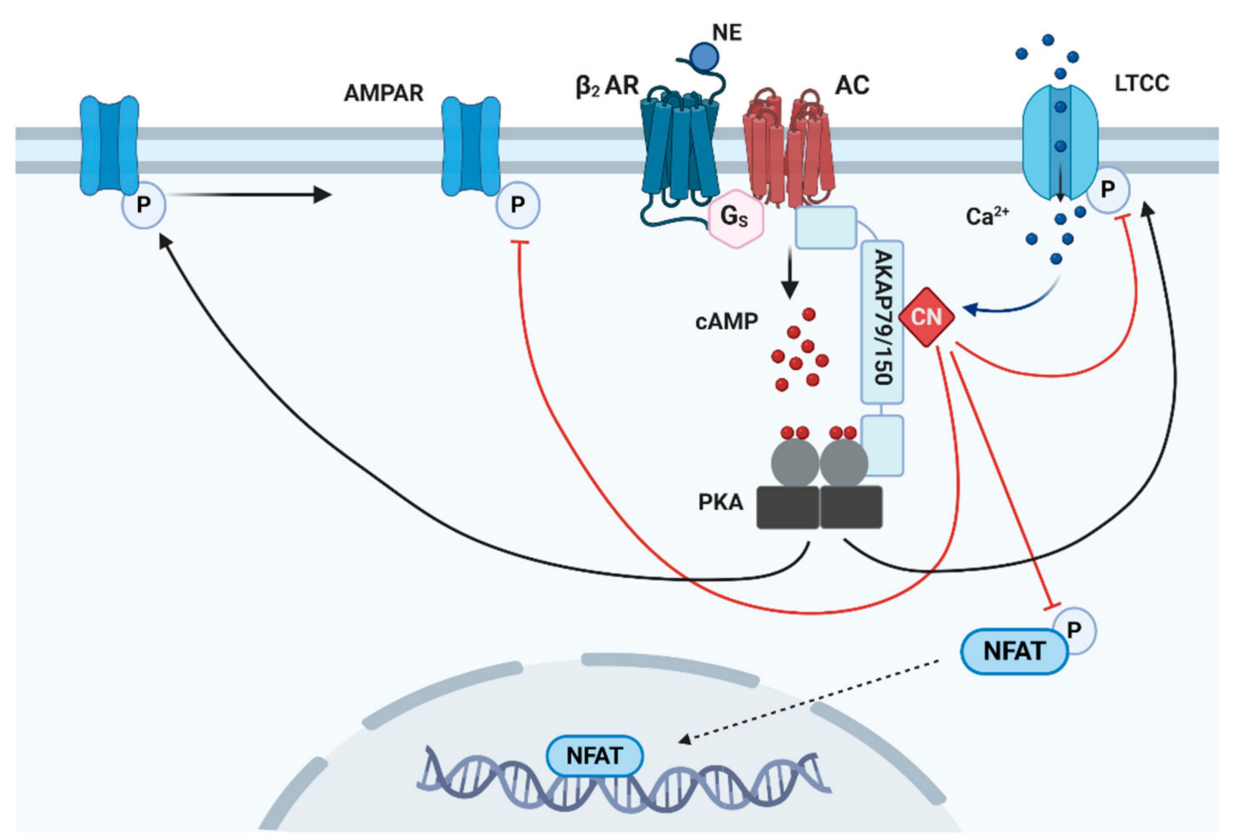

Figure 3. AKAP79/150 is involved in the coordination of synaptic plasticity. At the PSD, AKAP79/150 assembles a multiproteic complex containing $\beta_{2}$-ARs, AMPARs, PKA, CaN and an adenylyl cyclase (likely AC5). This complex is involved in NMDAR-independent LTP, where stimulation of $\beta_{2}$-ARs (by norepinephrine, NE) results in increased PKA dependent phosphorylation of AMPAR GluR1 and of $\mathrm{CaV}_{1.2}$ LTCCs. PKA phosphorylation promotes exocytosis, lateral diffusion and synaptic accumulation of AMPARs, and increases the opening probability of both AMPAR and LTCCs. Activation of $\mathrm{CaN}$ by $\mathrm{Ca}^{2+}$ influx through LTCC counteracts phosphorylation of both LTCC, as a negative feedback regulation to hinder $\mathrm{Ca}^{2+}$ entry, and AMPAR. Dephosphorylated AMPAR are removed from the synapse (not shown), leading to LTD. Moreover, activation of CaN leads to the dephosphorylation of NFAT, promoting its translocation in the nucleus, where it can act as transcriptional activator/repressor. Persistent $\mathrm{CaN}$ activation leads to down-regulation of NFAT targets including synaptic genes, resembling the transcriptional profiles encountered in human AD brain. A similar complex assembled by AKAP79/150 close to NMDAR (not shown) mediates LTP and contains AMPAR, PKA, CN and a $\mathrm{Ca}^{2+}$-activated AC (likely AC1 or AC8). Created with BioRender.com. 
During ageing, PKA signalling in the brain undergoes profound variations that appear to be region-specific. For instance, in aged hippocampus, PKA activity is reduced, which leads to defective CREB signalling and impaired memory consolidation $[184,185]$. The opposite trend emerges in the prefrontal cortex, where the cAMP/PKA axis appears to become overactive, impairing working memory capacity [178]. Information on the specific PKA subunits affected during ageing can be gathered by animal studies. Indeed, thanks to a number of mouse models lacking specific PKA subunits [186], it became evident that, although different types of $C$ and $R$ subunits are not redundant and their ablation gives rise to specific defects, it is not unusual for compensation events to occur.

Among the PKA catalytic subunits, ablation of $\mathrm{C} \alpha$ results in increased prenatal mortality, with the $1 / 3$ of the homozygote mice that survive presenting severe growth defects [187], attributed to low levels of epidermal growth factor receptor [188]. On the other hand, ablation of $C \beta$ resulted in decreased basal PKA activity in the amygdala, hippocampus, and cortex, which was connected to learning deficiencies. These findings suggested a role of $C \beta$-mediated signalling in memory, albeit with some strain-specific genetic variability in the phenotypes [189]. Later work showed that overfed C $\beta$ KO mice remained lean and were protected against steatosis, dyslipoproteinemia and insulin resistance. Interestingly, females were more protected than males, suggesting sex-dependent variations [190]. A recent report proposed that the increased glucose tolerance and metabolic rate of $C \beta \mathrm{KO}$ mice could depend on increased sympathetic outflow stemming from alterations in presympathetic neuronal activity [191]. Indeed, $C \beta$ activity inhibits norepinephrine (NE) release from noradrenergic neurons; therefore, its ablation could result in increased NE secretion [191]. This mechanism however, would not fit well the cardioprotective effect observed in $C \beta \mathrm{KO}$ animals [192], as it is well established that prolonged NE increases can be detrimental for the heart in a PKA-dependent manner [193]. Nevertheless, sympathetic NE release could have an effect similar to temperature preconditioning, implicating slight increases in PKA activity with cardioprotective effects [194].

In addition to depletion of the PKA catalytic subunits, a number of animal models targeting the regulatory subunits of PKA have been generated. Mice lacking RI $\alpha$ die during gestation due to failure of normal mesodermal development, most likely because of excess PKA activity [195]. Contrary to RI $\alpha$, ablation of RII $\beta$ and RII $\alpha$ results in milder phenotypes. $\mathrm{RII} \alpha \mathrm{KO}$ mice are resistant to diet-induced obesity, present higher glucose tolerance and are protected from hepatic steatosis. Interestingly, these characteristics, as with the $C \beta \mathrm{KO}$ animals, are more pronounced in females [196]. Similarly to RII $\alpha$, deletion of RII $\beta$ results in lean animals that are resistant to diet-induced obesity and fatty liver development. RII $\beta$ $\mathrm{KO}$ animals display a compensatory increase of $\mathrm{RI} \alpha$, which results in overactive PKA due to the higher affinity of these subunits for cAMP. As a result of increased PKA activity, RII $\beta$ $\mathrm{KO}$ animals display higher uncoupling protein induction and elevated metabolic rates [197]. Subsequent studies suggested that PKA holoenzymes containing RI $\alpha$ subunits could not functionally substitute the RII $\beta$-based PKA in its inhibitory action on the insulin-dependent activation of mitogen-activated protein kinase (MAPK) [198]. On the contrary, in RII $\beta$ KO mice the abundance of RI $\alpha$-based PKA resulted in increased basal lipolysis that was scarcely induced, however, by $\beta$-AR stimulation. These differences could be attributed to the altered compartmentalization of RI $\alpha$-based versus RII $\beta$-based PKA, which is required for the efficient transduction of signals that modulate lipolysis [199]. In fact, it is well established that only a small number of AKAPs can engage both RI and RII subunits, with the majority of these tethers binding selectively RI- or RII-based PKA holoenzymes. Based on this, compensatory events between RI and RII could reconstitute the activity of PKA however most likely cannot fully restore the subcellular compartmentalization of PKA. Interestingly, RII $\beta$ ablation resulted in increased lifespan and was beneficial to several age-related phenomena such as obesity, weight loss at end of life, cardiac hypertrophy, insulin resistance and the incidence and severity of age-related pathologies, albeit these effects were more pronounced in males [190]. The anti-ageing effects of PKA ablation thus seem to vary depending on the gender, as well as on model organisms. For instance, 
PKA deficiency extends lifespan in yeast [200], while on the contrary, PKA activation results in longevity in both C. elegans [201] and D. melanogaster [202]. Taken together, these data suggest a pivotal role for the cAMP/PKA pathway in ageing, making this cascade an appealing target for age-related disease research.

\subsubsection{AKAPs}

Despite the importance of compartmentalization in the functional outcomes of the cAMP signalling pathway, the effects of altered PKA subcellular targeting on ageing and neurodegeneration have been scarcely investigated. Indirect evidences on this matter can be gathered by studying the effects of AKAPs, the proteins responsible for the subcellular distribution of PKA. However, while AKAPs have been implicated in the pathophysiology of many human diseases [203,204], their role in age-related pathologies has been less appreciated and investigated, and only a limited number of studies have addressed the possible connection between altered cAMP/PKA signals and AKAP function in ageing and age-related cognitive decline. A well-characterized cascade revolves around AKAP79/150, that is involved in the coordination of NMDAR-independent LTP, in which stimulation of $\beta_{2}$-ARs results in increased PKA dependent phosphorylation of AMPAR GluR1 at Ser-845 [205], and of $\mathrm{CaV}_{1.2}$ LTCCs [206,207]. The $\mathrm{CaV}_{1.2}$ channel controls LTP, learning performance and the formation of spatial memory [208]. The temporal signature and intensity of $\mathrm{CaV}_{1.2}$-depedent $\mathrm{Ca}^{2+}$ signals are regulated by a multiproteic complex assembled by AKAP79/150, containing PKA, $\beta_{2}$-ARs $[209,210]$, AMPARs, CaN and an adenylyl cyclase [211,212]. Thanks to the scaffolding role of AKAP79/150, CaV 1.2 phosphorylation and consequently function are finely regulated: $\beta_{2}$-AR stimulation activates AKAP79/150-targeted PKA which phosphorylates $\mathrm{CaV}_{1.2}$ on S1928 to enhance its channel activity, whereas, on the contrary, $\mathrm{Ca}^{2+} / \mathrm{CaM}$-activated $\mathrm{CaN}$ counteracts PKA-mediated enhancement, as a negative feedback regulation to hinder $\mathrm{Ca}^{2+}$ entry [211,213] (Figure 3).

Animal models lacking AKAP79/150 (AKAP79/150 KO) or expressing a mutant version unable to bind PKA (AKAP150 $\triangle$ PKA) result in flawed PKA recruitment and distribution within the PSD, and consequently display learning and memory defects $[106,107,214]$. The perturbations in the plasticity of excitatory hippocampal synapses observed during ageing can be a consequence of deregulation in AMPAR trafficking [215], which is modulated by CaMKII [216-218] and CaN [219,220], and of alterations in $\mathrm{CaV}_{1.2}$ function, that are found in several neurologic disorders including PD and AD [221].

\subsection{5. $\mathrm{Ca}^{2+}$}

In the excitable cells of the brain, $\mathrm{Ca}^{2+}$ regulates a plethora of molecular processes. Interestingly, during ageing, adjustments in $\mathrm{Ca}^{2+}$ handling act as a compensatory mechanism against age-related neuronal dysfunction. For instance, in aged peripheral autonomic neurons, reduction in the ability of ER to uptake $\mathrm{Ca}^{2+}$, due to decreased Sarco-Endoplasmic Reticulum Calcium ATPase (SERCA) activity, is compensated by increased $\mathrm{Ca}^{2+}$ extrusion and buffering by the Plasma Membrane Calcium ATPase (PMCA) and by mitochondria, respectively [222]. However, these compensatory mechanisms are not resolutive and can eventually became harmful. For example, prolonged increases in intramitochondrial $\mathrm{Ca}^{2+}$ can trigger pathological responses that eventually lead to cell death. Impaired $\mathrm{Ca}^{2+}$ handling is a common age-related feature also in other neuron populations, including those of the basal forebrain [223,224]. In ageing rat neurons for example, despite the fact that subtle increases in $\mathrm{Ca}^{2+}$ influx through voltage-gated $\mathrm{Ca}^{2+}$ channels are buffered by $\mathrm{Ca}^{2+}$-binding proteins and basal $\left[\mathrm{Ca}^{2+}\right]$ appears constant, synaptic transmission is impaired leading to cognitive deficiencies. In an in vitro model of aged rat hippocampal neurons, neuronal ageing is associated to increased transfer of $\mathrm{Ca}^{2+}$ from ER to mitochondria and impairment of store-operated $\mathrm{Ca}^{2+}$ entry (SOCE), a $\mathrm{Ca}^{2+}$ entry pathway related to memory storage $[225,226]$. The validity of this experimental model was demonstrated by the finding that altered expression of Orai1/Stim1 (involved in SOCE) and of $\mathrm{Ca}^{2+}$ channels, such as the NMDARs, the inositol triphosphate receptors (IP3Rs) and the mitochondrial $\mathrm{Ca}^{2+}$ 
uniporter (MCU), mirrors the events observed in ageing neurons in vivo [227]. In brain tissues from aged monkeys, both the mitochondria $\mathrm{Ca}^{2+}$ buffering capacity as well as their bioenergetic potential are reduced, and are associated to motor decline [228]. The use of genetically encoded $\mathrm{Ca}^{2+}$ sensors demonstrated an elevation in $\mathrm{Ca}^{2+}$ influx in the presynaptic terminals of aged hippocampal neurons that resulted in increased basal $\mathrm{Ca}^{2+}$ levels. Consequently, these animals displayed alterations in hippocampal-dependent behavioral tasks such as spatial memory [229]. A key player in neuronal $\mathrm{Ca}^{2+}$ dynamics appears to be the FK506-binding protein 12.6/1b (FKBP1b). This protein negatively regulates both the $\mathrm{ER} \mathrm{Ca}^{2+}$ release through ryanodine receptors (RyRs) and its influx through LTCCs [230]. FKBP1b was found downregulated in hippocampal cells of aged rats and, interestingly, when its expression was restored, $\mathrm{Ca}^{2+}$ dysregulation was repaired, with consequent reduced cognitive impairment and ameliorated memory in ageing animal models [231,232].

\section{Alterations of cAMP Compartmentalization in Neurodegenerative Diseases}

\subsection{Alzheimer's Disease (AD)}

While a small percentage of AD patients develop the disease early due to genetic causes, for the common late onset Alzheimer's disease (LOAD), a major risk factor is ageing [233]. In AD, cAMP levels are found often decreased, but also increased or unchanged, depending on specific brain regions (reviewed in [9]). However, in many studies, PKA activity appears to be suppressed $[9,19,234]$. Tau is an unfolded, highly soluble protein involved in tubulin assembly, microtubules stabilization and stress granule axonal trafficking [235,236]. In a mouse model of tauopathy, activation of PKA early in the disease was shown to be beneficial in attenuating Tau-driven proteasome dysfunction, leading to lower levels of aggregated Tau and improved cognitive performance $[237,238]$, underlying the fundamental role of PKA in phosphorylating proteasome subunits. Another important target of the CAMP/PKA axis, involved in AD pathogenesis, is CREB (reviewed in [239]). A drop in the phosphorylation of CREB leads to the decreased expression of many genes, including other transcription factors such as PGC1 $\alpha$ (with implications for mitochondrial biogenesis), and NFkB (driving inflammatory response) [19,240-244].

The decrease in CREB activity could be counteracted by PDE inhibition, which increased the interest on the therapeutic potential of targeting these enzymes. For example, a nonspecific PDE inhibitor, propentofylline, had positive outcomes in animal models and several phase III trials, improving many AD phenotypes [19,245,246]. Notwithstanding its beneficial effects, which persisted also after treatment cessation, the use of this drug in human patients has been abandoned [19]. In fact, the large number of PDE isoforms expressed in human brain, together with their non-uniform expression patterns, represents a significant obstacle in the therapeutic exploitation of these enzymes [247]; therefore, the main challenge consists in the development of highly specific molecules, targeting single PDE isoforms [19]. For example, a number of clinical trials are currently testing PDE4 inhibitors for the treatment of LOAD [248] (https: / / clinicaltrials.gov). Indeed, the PDE4specific inhibitor rolipram has been considered as a promising treatment for NDs [249,250], and the PDE4D isoform, involved in the regulation of memory, is found upregulated in AD, suggesting a role in memory loss [251]. Specific PDE4 inhibitors such as rolipram and roflumilast, but also the similarly acting resveratrol [252,253], could be used to increase cAMP levels and modify the progress of AD [19,247,252]. Resveratrol-dependent cAMP elevation enhances the deacetylase activity of Sirt1 [62] through the activation of the EPAC1-AMPKSirt1 axis [252]. In addition, both rolipram and resveratrol indirectly drive mitochondrial biogenesis [252] and can prevent aged-related mitochondrial dysfunction [19].

In opposition to the beneficial effect that PDE inhibition can have on the PKAdependent phosphorylation of CREB and of the proteasome, it has been found that, in brains of LOAD patients and AD mouse models, RyRs are leaky, in part owing to their excessive PKA-dependent phosphorylation [254,255]. Taken together, the above cited examples highlight the relevance of the correct compartmentalization of the cAMP/PKA signals and underline the importance of identifying the PDEs responsible for each domain 
and developing highly specific PDE inhibitors $[66,256,257]$ that could exert a therapeutic action without disrupting essential cAMP/PKA microdomains. A further cautionary note should be made on the use of mice as sole animal model; indeed, mice appear as good models for the study of early-onset genetic AD, but, due to their brain anatomy and short lifespan, are less optimal for studying the age-related LOAD [257]. For instance, in mouse models (but not in human LOAD, see below), the production of soluble $\mathrm{A} \beta$ oligomers is sufficient to initiate the cognitive deficits characteristic of the disease, before the insurgence of amyloid plaques [258]. Several lines of evidence suggest that chronic $\mathrm{CaN}$ activation may be involved in both the cognitive and degenerative effects of $A \beta$ [259-262]. Activation of AKAP79/150-tethered CaN by A $\beta$-triggered increases in LTCC-dependent $\mathrm{Ca}^{2+}$ influx leads to the dephosphorylation of multiple NFAT phosphorylation sites and regulates NFAT signalling [263] (see Figure 3). Indeed, persistent CaN activation leads to down-regulation of NFAT targets including synaptic genes, resembling the transcriptional profiles encountered in human AD brain [264]. However, despite the well-established role of AKAP79/150 in CaN targeting in the PSD, there is no direct evidence that uncoupling of $\mathrm{CaN}$ from the AKAP79/150 signalling complex can contrast A $\beta$-dependent synaptic dysfunction.

On the contrary, in human brains affected by LOAD, the Tau aggregation precedes amyloid plaques deposition [265]. In AD, Tau becomes hyperphosphorylated and unable to bind the microtubules, and aggregates forming intracellular NFTs, both in neurons [22] and astrocytes [23]. A very recent study highlighted that changes in the phosphorylation state of Tau are associated with variations in structural, metabolic, neurodegenerative and clinical markers of disease. Interestingly, some of these changes begin simultaneously to the initial increases in $\beta$-amyloid aggregates, two decades before the development of Tau aggregates and the insurgence of the pathology [266]. In addition, amyloid plaques are found in the brains of elderly individuals that do not present cognitive impairments, while on the contrary, cognitive symptoms seem more likely to occur in brains presenting Tau tangles $[267,268]$. In line with these considerations, strategies to reduce $A \beta$ have limited benefit to patients in early stages of LOAD [269].

In neurons, the physiological role of Tau is to stabilize the microtubular scaffold of axons and dendrites in response to regulatory events that are translated by cycles of phosphorylation/dephosphorylation, involving several kinases including PKA [270]. This dynamic equilibrium is lost in pathology, resulting in hyperphosphorylated Tau. As a consequence, microtubules are destabilized and collapse, disabling intracellular transport $[24,25]$. Thus, dysregulated cAMP/PKA, but also $\mathrm{Ca}^{2+}$ signalling play major roles in the pathways that lead to Tau hyperphosphorylation and to cognitive deficits during ageing [178,271-273], priming Tau for hyperphosphorylation by both wt and truncated forms of glycogen synthase kinase $3 \beta$ (GSK3 $\beta$ ), the latter associated with Tau pathology in LOAD [274]. This process appears connected to GSKIP (GSK3 $\beta$-Interacting Protein), a small cytosolic AKAP [275] that directly interacts with both GSK3 $\beta$ and PKA, coordinating their actions. The involvement of a cAMP/GSKIP/GSK3 $\beta / P K A / T a u$ axis in Tau phosphorylation was recently studied in SHSY5Y cells and confirmed in cerebrospinal fluid and pluripotent stem cells of AD patients [276]. The authors demonstrated the existence of a molecular complex consisting of GSKIP, RII-based PKA, GSK3 $\beta$ and Tau (tethered to GSK3 $\beta$ ) that enhances the cAMP/PKA signalling, resulting in increased Tau phosphorylation at distinct PKA-dependent phosphorylation sites (Ser214, Ser262, and Ser409) during AD pathogenesis [276]. Among several Tau phosphorylation sites associated with neurodegeneration $[277,278]$, Ser262 hyperphosphorylation significantly reduces the affinity of Tau for microtubules [279] and is associated with the initial steps of AD [280]. Interestingly, a high-throughput siRNA-based screening investigating the proteins involved in Tau Ser262 phosphorylation identified another AKAP (AKAP13) as a protein able to induce S262 phosphorylation [281]. While this study suggested that AKAP13 could form a multiproteic signalling complex to regulate Tau phosphorylation and microtubule dynamics 
in response to extracellular stimuli, unequivocal evidence for a direct connection between AKAP13 and Tau phosphorylation is lacking.

Hyperphosphorylated Tau is prone to aggregation, eventually leading to NFTs [282], which develop in the entorhinal cortex (ERC) before the first symptoms of the disease, and extend to the deep layers of the ERC, the hippocampus and the dorsolateral prefrontal cortex (dlPFC) during the early signs of the pathology. On the contrary, the primary visual and auditory cortex remain unaffected until the very late stages of the disease [265]. Interestingly, the role of cAMP in dIPFC and ERC is quite different from its function in the visual cortex. In fact, neurons of the visual cortex rely mostly on AMPARs, and respond positively to cAMP/PKA signalling by increasing their sensory-evoked firing [283]. On the contrary, neurons in dIPFC can maintain firing even in the absence of sensory stimulation and rely on stimulation by NMDARs [284]. In these cells, cAMP reduces neuronal firing [285], and, consequently, synaptic strength. The cAMP-dependent reduction of synaptic strength in the association cortices is likely to be a physiological safety mechanism, fundamental for appropriate stress responses due to the release of catecholamines and consequent cAMP increases. However, persistent high levels of cAMP, in conjunction with high $\mathrm{Ca}^{2+}$, can lead to excessive PKA-dependent phosphorylation of Tau [274]. Overall, it is becoming clear that stress-induced dysregulation of signalling events is key for physiological ageing and the pathogenesis of LOAD [286,287]. These considerations highlight the need of strict regulation of the cAMP levels by PDEs [2], and of PKA activity by phosphatases [5], and could explain why stress is a risk factor especially in females, who are more prone to develop stress-induced prefrontal cortex dysfunctions [288] and LOAD [289].

Finally, it is becoming increasingly clear that also altered intracellular $\mathrm{Ca}^{2+}$ responses are a common feature in $\mathrm{AD}$, especially in cases of familial mutations in the genes encoding APP or the $\gamma$-secretase/presenilin1 and 2 (PS1/PS2) (reviewed in $[290,291])$. However, the pathogenic mechanisms through which mutations in APP and PSs affect intracellular $\mathrm{Ca}^{2+}$ are not fully understood [292]. The " $\mathrm{Ca}^{2+}$ hypothesis" envisages that PS mutations result in increased ER Ca ${ }^{2+}$ content and excessive $\mathrm{Ca}^{2+}$ release in the cytosol, which affects APP processing, increases neuronal sensitization to $A \beta$ and eventually leads to cell death [293]. In mouse models of $\mathrm{AD}$, intracellular $\mathrm{Ca}^{2+}$ overload is caused by the deposition of $\beta$ amyloid plaques in at least $20 \%$ of neurites, especially near the sites of plaque formation, underlying the fact that senile plaques are focal sources of toxicity [294]. Thus, on one hand, cytosolic $\mathrm{Ca}^{2+}$ overload seems responsible of structural and functional derangement of neuronal networks, while, on the other, $\mathrm{Ca}^{2+}$ homeostasis and compartmentalization is deeply altered by amyloid plaque deposition. In addition, dysfunctional neuronal $\mathrm{Ca}^{2+}$ homeostasis supports the onset of the inflammatory response in glial cells (astrocytes and microglia), accelerating the progression of the disease [295]. The involvement of deregulated $\mathrm{ER} \mathrm{Ca}^{2+}$ release in the pathways that lead to the insurgence and progression of $\mathrm{AD}$ is still debated [296]. PSs, transmembrane proteins that support the cleavage of the APP by $\gamma$-secretase, function as SR/ER Ca ${ }^{2+}$ leak channels $[297,298]$. Genetic ablation of PSs in primary hippocampal neurons of mice reduced the expression and activity of RyRs [299]. The resulting perturbation in $\mathrm{Ca}^{2+}$ handling may be one of the early pathogenic events that lead to presynaptic dysfunction in AD. More recent work found that the activity of the brainspecific RyR2 isoform is altered in $\mathrm{AD}$, leading to abnormalities in the metabolism of $\beta$ amyloid. In particular, RyR2 undergoes post-translational modifications (PKA-dependent phosphorylation, oxidation, nitrosylation) that destabilize its macromolecular complex with FKBP1b and lead to abnormal $\mathrm{Ca}^{2+}$ signaling in brains of $\mathrm{AD}$ patients [255]. Other studies found a number of alterations in the expression patterns of RyR2 isoforms in postmortem mid-temporal cortices from individuals with mild cognitive impairment and in $\mathrm{AD}$ brains [300], further consolidating the idea that RyR expression may reflect the onset of pathologic signalling events at early stages of the disease. Dysregulated $\mathrm{Ca}^{2+}$ release from the ER is coupled to mitochondrial $\mathrm{Ca}^{2+}$ overload and can lead to neuronal cell death [301]. Mitochondrial $\mathrm{Ca}^{2+}$ overload was found in APP/PS1 transgenic animals and wt littermates treated with soluble $\beta$ amyloid peptide, suggesting a connection between $\beta$ amyloid 
aggregation/deposition and mitochondrial $\mathrm{Ca}^{2+}$ dynamics. Interestingly, inhibition of mitochondrial $\mathrm{Ca}^{2+}$ uptake prevented amyloid plaque deposition in vivo [302]. In line with these findings, mitochondrial $\mathrm{Ca}^{2+}$ efflux was found impaired in experimental models of $\mathrm{AD}$, while the NCX3 was lost in the frontal cortex of non-familial AD patients before the insurgence of neuropathology and memory decline [303].

\subsection{Parkinson's Disease (PD)}

Age is a major risk factor for $\mathrm{PD}$ [304], characterized by the progressive degeneration of dopamine-producing neurons within the substantia nigra, that project to the striatum forming the nigrostriatal pathway [13]. The principal targets of dopamine are the medium spiny neurons (MSNs) in the striatum [14], that express dopamine D1 or D2 receptors (D1Rs or D2Rs). Dopaminergic neuron degeneration underlies many of the motor symptoms of PD patients [11,13].

The levels of PDE10A, which is highly expressed in the striatum [12,305,306], appear to decrease during the onset of $\mathrm{PD}$, and to correlate with the progression and the severity of the symptoms [307]. Despite these evidences, PDE10-specific inhibitors were tested and found to be neuroprotective in PD animal models [308]. Notably, similar reduction of PDE10A associated with disease progression and beneficial effects of PDE10 inhibition are observed in HD [309,310]. In rodent brains, the highest levels of PDE10A are observed in the striatum and olfactory tubercle and much less in the cortex, hippocampus and cerebellar granular cells [311]. Such spatially confined expression renders unlikely the possibility that the beneficial effects for PD are due to PDE10 inhibition in non-neuronal tissues, and, at the same time, indicates PDE10A as an ideal target. Intriguingly, human mutations in PDE10A lead to loss of striatal PDE10A and are accompanied by an hyperkinetic movement disorder with onset in infancy, indicating that PDE10A plays a key role in regulating striato-cortical movement control [312].

Of note, increased cAMP levels in hyperkinetic movement disorders are strongly suggested also by the discovery of AC5-activating mutations in affected individuals $[313,314]$. AC5 is the most abundant AC subtype in the dorsal striatum, and it was proposed to play a role also in L-DOPA induced dyskinesia [315] (LID). L-DOPA is used to treat PD, but its prolonged use causes abnormal involuntary movements, called dyskinesia. In comparison to wt littermates, AC5 KO mice treated with L-DOPA show a reduction of LID and a decrease in the phosphorylation of ERK1/2, MSK1, and histone H3. Because of its involvement in mediating LID, AC5 has been considered as a possible therapeutic target in the treatment of LID in PD patients [315].

In MSNs, D1R stimulation activates the cAMP/PKA axis, promoting the phosphorylation of the NMDAR-NR2B subunit and the AMPAR-GluR1 (also called GluA1) subunit [316], thus regulating the excitability of striatal projection neurons and the postsynaptic targeting of AMPARs [316-318]. However, the dopamine-PKA axis has numerous cellular targets [316], therefore AKAP-dependent PKA compartmentalization is essential for adequate responses, and the deregulation of these complexes may be involved in the synaptic dysfunction observed in PD. This possibility is clearly suggested by the findings that the leucine-rich repeat kinase 2 (LRRK2), which has been found mutated in familiar forms of PD [319], can act as an AKAP and complex with PKA RII $\beta$ [318,320]. Interestingly, Parisiadou and colleagues suggested that LRKK2 localizes PKA along the dendritic shaft; upon cAMP increases, PKA is activated and phosphorylates GluR1 and Cofilin within the dendritic spines [318], affecting synaptic plasticity and spine morphology. The access of PKA to the spines is crucial [321] and thus is tightly controlled by AKAPs. For instance, AKAP79/150 vehicles PKA in the vicinity of its targets within the dendritic spine, while LRRK2 and MAP2 [322] are AKAP-like proteins that tether PKA in the dendritic shaft. Upon disruption of LRRK2-PKA RII $\beta$ binding, as in the PD-related missense mutation LRRK2 R1441C [323], PKA is likely free to translocate from shafts into the spines, resulting in increased GluR1 phosphorylation in response to D1Rs and morphological alterations [321]. Importantly, LRRK2-dependent regulation of PKA signalling is pre- 
dominant during the synaptogenesis [321], a phase where PKA is crucial [324], which could explain the changes in spine morphology and altered synaptic transmission of MSNs detected in PD brains [325]. In addition to binding directly PKA, a study found that LRRK2 can complex also with AKAP8 [326], suggesting that LRRK2 can regulate the subcellular distribution of PKA also in an indirect way, through its interactions with additional AKAPs [322]. The involvement of cAMP/PKA signalling in the pathophysiology of several different LRRK2 mutants, affecting mitochondrial homeostasis [327] and autophagy [328,329], clearly suggests a fundamental role for the disruption of PKA compartmentalization in the pathogenesis of PD.

A cellular model of PD (SH-SY5Y cells with reduced expression of the endogenous mitochondrial kinase PINK1) exhibited mitochondrial fragmentation, increased mitochondriaderived superoxide, and induction of compensatory mitophagy. Mitochondrial dynamics is an important feature for the organelle function and trafficking to and from synapses $[43,44]$ and is regulated by a small number of proteins including Drp1, a key regulator of mitochondrial fission [330,331]. In response to pro-fission stimuli, Drp1 is activated and migrates from the cytosol to the OMM; on the contrary, upon PKA-dependent phosphorylation Drp1 is inhibited, in both its GTPase activity and its translocation to the OMM [105,332,333]. Interestingly, overexpression of AKAP1, a protein that targets PKA to mitochondria, reversed the phenotypes attributed to loss of PINK1, and rescued parameters of mitochondrial respiratory dysfunction. In addition, mimicking PKA-dependent phosphorylation of Drp1 recapitulated many of the protective effects of AKAP1/PKA, indicating that redirecting endogenous PKA to mitochondria can compensate for deficiencies in PINK1 function, highlighting the importance of compartmentalized signalling networks in mitochondrial quality control and pathophysiology [89].

PKA-dependent inactivation of Drp1 was effectively enhanced by overexpression of wt AKAP1, but not of a PKA-binding deficient mutant, clearly indicating that mitochondrial fragmentation is inhibited by OMM-tethered PKA [94]. These data are in line with our recent finding that physiological cAMP elevations in both primary neonatal cardiac myocytes [5] and primary fibroblasts [4] resulted in enhanced PKA-dependent phosphorylation at the OMM but not in the cytosol and resulted in Drp1-dependent mitochondrial elongation [5]. The AKAP1/PKA signalosome appears to be protective against a variety of cellular stresses including, for instance, glutamate-induced oxidative stress [334]. Taking in consideration that oxidative stress is a major contributing factor in ageing-related NDs [335], it is tempting to consider this complex as a possible therapeutic target.

In addition to cAMP, intracellular $\mathrm{Ca}^{2+}$ transients and mitochondrial $\mathrm{Ca}^{2+}$ overload are also important hallmarks of PD (reviewed in [336-338]). The link between mitochondrial $\mathrm{Ca}^{2+}$ dysfunction and PD firstly emerged a decade ago and was consolidated by the identification of PD-causing mutations in genes connected with intracellular $\mathrm{Ca}^{2+}$ handling and mitochondrial function. In particular, the loss of PINK-1 causes massive mitochondrial $\mathrm{Ca}^{2+}$ overload due to the reduced activity of the mitochondrial NCX3 [339]. Additionally, in intact mitochondria, PINK1 directly interacts and phosphorylates the electrogenic mitochondrial $\mathrm{Ca}^{2+} / \mathrm{H}^{+}$antiporter LETM1 at Thr192, reducing $\mathrm{Ca}^{2+}$ entry [340]. In fact, overexpression of the phosphomimetic LETM1-T192E protects PINK1-deficient neurons from cell death. The link of mitochondria to the loss of dopaminergic neurons in PINK1Y431 mutant and PINK1 ${ }^{-/-}$zebrafish (Danio rerio) was consolidated by the finding that inhibition of the mitochondrial calcium uniporter (MCU) decreased neuronal death and ameliorated the mitochondrial respiratory chain function [341,342].

The deglycase DJ-1 is a pleiotropic protein associated with PD that is involved in ERmitochondrial tethering and translocates to mitochondria under stress conditions (e.g., oxidative stress). DJ-1 can be found within the mitochondria-associated membranes (MAMs) in a macromolecular complex that guarantees $\mathrm{Ca}^{2+}$ transfer from ER to mitochondria [343,344]. In brains of DJ-1 KO mice, this complex precipitates in aggregates resulting in abnormal MAMs formation and function. Interestingly, these defects are rescued by the expression of wild-type DJ-1 but not by the expression of its PD-associated 
mutant L166P. Abnormalities in $\mathrm{Ca}^{2+}$ homeostasis are common determinants in age-related diseases as well as in neuropathological conditions, although several pieces of evidence suggest that alterations in intracellular $\mathrm{Ca}^{2+}$ handling do not necessarily result in deterioration of cellular function, thanks to compensatory mechanisms. Nevertheless, novel therapeutic strategies aiming at restoring dysfunctional $\mathrm{Ca}^{2+}$ homeostasis represent a promising route to implement the treatment of many NDs [345-348].

\section{Final Considerations}

As our understanding of the major cell signaling cascades advances, it is becoming clear that these evolutionarily conserved pathways may represent the "weakest link" in the process of ageing and age-related diseases. From one side, cellular signalling events guarantee the ability of cells to communicate with the extracellular environment and are at the basis of virtually all adaptive responses. On the other side, however, these signalling pathways require the constant maintenance of delicate equilibria between several molecular components, which comes with a cost, both of energy consumption but also, and most importantly, of system fragility. In fact, age-dependent alterations in a single component can result in suboptimal adaptive responses affecting cellular homeostasis and having a causal role in the development of age-related diseases. While our main research efforts have been concentrating on measurable biochemical changes (transcriptional, posttranslational, etc.), little is known about the effects of ageing on the subcellular distribution of signalling pathways, a feature that is crucial for the proper generation of signalling networks and adaptive responses. Thanks to the continued development and improvement of methodologies that allow us to observe signalling events with great spatial definition it is only a matter of time until the effects of ageing on signalling topology, as well as the effect of disrupted topology on the ageing process, will emerge.

From a philosophical point of view, ageing divided even the most brilliant minds. In fact, while Plato considered old age a great liberator from earthbound desires and distractions, that enabled humans to achieve knowledge and good life, Aristotle detested old age as the decline that was both physical and moral. In a similar manner, in a debate held 2300 years after Plato and Aristotle, some of the foremost experts in ageing biology were unable to reach an undivided consensus of what ageing is [349]. It is clear that the road is long before fully understanding ageing and its mechanisms, however, we believe, it is safe to assume that the pressing need for discovering novel healthy-ageing interventions would have united the opinions of all, scientists and Greek philosophers.

Author Contributions: Original draft preparation: G.D.B., L.F.I., N.C.S., S.Z., F.G., F.C., A.G., K.L. Figure preparation: L.F.I. Review and editing: G.D.B., K.L. All authors have read and agreed to the published version of the manuscript.

Funding: This work was supported by grants CARIPARO Foundation excellence grant award (SIGMI), Italian Ministry of University and Education (PRIN- 2017BF3PXZ).

Conflicts of Interest: The authors declare no conflict of interest. The funders had no role in the design of the study; in the collection, analyses or interpretation of data; in the writing of the manuscript; or in the decision to publish the results.

\section{References}

1. Nikolaev, V.O.; Moshkov, A.; Lyon, A.R.; Miragoli, M.; Novak, P.; Paur, H.; Lohse, M.J.; Korchev, Y.E.; Harding, S.E.; Gorelik, J. 2-Adrenergic Receptor Redistribution in Heart Failure Changes cAMP Compartmentation. Science 2010, 327, $1653-1657$. [CrossRef]

2. Baillie, G.S.; Tejeda, G.S.; Kelly, M.P. Therapeutic targeting of $3^{\prime}, 5^{\prime}$-cyclic nucleotide phosphodiesterases: Inhibition and beyond. Nat. Rev. Drug Discov. 2019, 18, 770-796. [CrossRef]

3. Torres-Quesada, O.; Mayrhofer, J.E.; Stefan, E. The many faces of compartmentalized PKA signalosomes. Cell. Signal. 2017, 37, 1-11. [CrossRef]

4. Grisan, F.; Burdyga, A.; Iannucci, L.F.; Surdo, N.C.; Pozzan, T.; Di Benedetto, G.; Lefkimmiatis, K. Studying $\beta 1$ and $\beta 2$ adrenergic receptor signals in cardiac cells using FRET-based sensors. Prog. Biophys. Mol. Biol. 2019. [CrossRef] 
5. Burdyga, A.; Surdo, N.C.; Monterisi, S.; Di Benedetto, G.; Grisan, F.; Penna, E.; Pellegrini, L.; Zaccolo, M.; Bortolozzi, M.; Swietach, P.; et al. Phosphatases control PKA-dependent functional microdomains at the outer mitochondrial membrane. Proc. Natl. Acad. Sci. USA 2018, 115, E6497-E6506. [CrossRef]

6. Gómez-Gómez, M.E.; Zapico, S.C. Frailty, cognitive decline, neurodegenerative diseases and nutrition interventions. Int. J. Mol. Sci. 2019, 20, 2842. [CrossRef] [PubMed]

7. Giralt, A.; Saavedra, A.; Alberch, J.; Pérez-Navarro, E. Cognitive dysfunction in Huntington's disease: Humans, mouse models and molecular mechanisms. J. Huntingtons. Dis. 2012, 1, 155-173. [CrossRef]

8. Aarsland, D.; Creese, B.; Politis, M.; Chaudhuri, K.R.; Ffytche, D.H.; Weintraub, D.; Ballard, C. Cognitive decline in Parkinson disease. Nat. Rev. Neurol. 2017, 13, 217-231. [CrossRef]

9. Kelly, M.P. Cyclic nucleotide signaling changes associated with normal aging and age-related diseases of the brain. Cell. Signal. 2018, 42, 281-291. [CrossRef]

10. Kim, J.; Kwon, J.T.; Kim, H.S.; Han, J.H. CREB and neuronal selection for memory trace. Front. Neural Circuits 2013, 7, 44. [CrossRef] [PubMed]

11. Kouli, A.; Torsney, K.M.; Kuan, W.-L. Parkinson's Disease: Etiology, Neuropathology, and Pathogenesis. In Parkinson's Disease: Pathogenesis and Clinical Aspects; Stoker, T.B., Greenland, J.C., Eds.; Codon Publications: Brisbane, AU, USA, 2018; pp. 3-26. ISBN 9780994438164.

12. Bollen, E.; Prickaerts, J. Phosphodiesterases in neurodegenerative disorders. IUBMB Life 2012, 64, 965-970. [CrossRef]

13. Houlden, H.; Singleton, A.B. The genetics and neuropathology of Parkinson's disease. Acta Neuropathol. 2012, 124, 325-338. [CrossRef]

14. Obeso, J.A.; Marin, C.; Rodriguez-Oroz, C.; Blesa, J.; Benitez-Temiño, B.; Mena-Segovia, J.; Rodríguez, M.; Olanow, C.W. The basal ganglia in Parkinson's disease: Current concepts and unexplained observations. Ann. Neurol. 2008, 64, S30-S46. [CrossRef] [PubMed]

15. Kordower, J.H.; Olanow, C.W.; Dodiya, H.B.; Chu, Y.; Beach, T.G.; Adler, C.H.; Halliday, G.M.; Bartus, R.T. Disease duration and the integrity of the nigrostriatal system in Parkinson's disease. Brain 2013, 136, 2419-2431. [CrossRef]

16. Park, S.B.; Kwon, K.Y.; Lee, J.Y.; Im, K.; Sunwoo, J.S.; Lee, K.B.; Roh, H.; Ahn, M.Y.; Park, S.; Kim, S.J.; et al. Lack of association between dopamine transporter loss and non-motor symptoms in patients with Parkinson's disease: A detailed PET analysis of 12 striatal subregions. Neurol. Sci. 2019, 40,311-317. [CrossRef]

17. Mayeux, R.; Stern, Y. Epidemiology of Alzheimer disease. Cold Spring Harb. Perspect. Med. 2012, 2. [CrossRef]

18. Albensi, B.C. Dysfunction of mitochondria: Implications for Alzheimer's disease. In International Review of Neurobiology; Academic Press Inc.: Cambridge, MA, USA, 2019; Volume 145, pp. 13-27. ISBN 9780128172247.

19. Sanders, O.; Rajagopal, L. Phosphodiesterase Inhibitors for Alzheimer's Disease: A Systematic Review of Clinical Trials and Epidemiology with a Mechanistic Rationale. J. Alzheimer's Dis. Rep. 2020, 4, 185-215. [CrossRef] [PubMed]

20. Van Giau, V.; Senanarong, V.; Bagyinszky, E.; An, S.S.A.; Kim, S. Analysis of 50 neurodegenerative genes in clinically diagnosed early-onset Alzheimer's disease. Int. J. Mol. Sci. 2019, 20, 1514. [CrossRef] [PubMed]

21. Kovacs, G.G. Tauopathies. In Handbook of Clinical Neurology; Elsevier B.V.: Amsterdam, The Netherlands, 2018; Volume 145, pp. 355-368.

22. Ercan-Herbst, E.; Ehrig, J.; Schöndorf, D.C.; Behrendt, A.; Klaus, B.; Gomez Ramos, B.; Prat Oriol, N.; Weber, C.; Ehrnhoefer, D.E. A post-translational modification signature defines changes in soluble tau correlating with oligomerization in early stage Alzheimer's disease brain. Acta Neuropathol. Commun. 2019, 7. [CrossRef]

23. Richetin, K.; Steullet, P.; Pachoud, M.; Perbet, R.; Parietti, E.; Maheswaran, M.; Eddarkaoui, S.; Bégard, S.; Pythoud, C.; Rey, M.; et al. Tau accumulation in astrocytes of the dentate gyrus induces neuronal dysfunction and memory deficits in Alzheimer's disease. Nat. Neurosci. 2020, 23, 1567-1579. [CrossRef]

24. Mandelkow, E.; Von Bergen, M.; Biernat, J.; Mandelkow, E.M. Structural principles of tau and the paired helical filaments of Alzheimer's disease. Brain Pathol. 2007, 17, 83-90. [CrossRef]

25. Duan, A.R.; Jonasson, E.M.; Alberico, E.O.; Li, C.; Scripture, J.P.; Miller, R.A.; Alber, M.S.; Goodson, H.V. Interactions between Tau and Different Conformations of Tubulin: Implications for Tau Function and Mechanism. J. Mol. Biol. 2017, 429, 1424-1438. [CrossRef] [PubMed]

26. Sisodia, S.S.; St George-Hyslop, P.H. $\gamma$-Secretase, notch, A $\beta$ and alzheimer's disease: Where do the presenilins fit in? Nat. Rev. Neurosci. 2002, 3, 281-290. [CrossRef] [PubMed]

27. Ittner, L.M.; Götz, J. Amyloid- $\beta$ and tau-A toxic pas de deux in Alzheimer's disease. Nat. Rev. Neurosci. 2011, 12, 67-72. [CrossRef] [PubMed]

28. Cline, E.N.; Bicca, M.A.; Viola, K.L.; Klein, W.L. The Amyloid- $\beta$ Oligomer Hypothesis: Beginning of the Third Decade. J. Alzheimer's Dis. 2018, 64, S567-S610. [CrossRef]

29. Selkoe, D.J.; Hardy, J. The amyloid hypothesis of Alzheimer's disease at 25 years. EMBO Mol. Med. 2016, 8, 595-608. [CrossRef]

30. Usenovic, M.; Niroomand, S.; Drolet, R.E.; Yao, L.; Gaspar, R.C.; Hatcher, N.G.; Schachter, J.; Renger, J.J.; Parmentier-Batteur, S. Internalized tau oligomers cause neurodegeneration by inducing accumulation of pathogenic tau in human neurons derived from induced pluripotent stem cells. J. Neurosci. 2015, 35, 14234-14250. [CrossRef]

31. Seyb, K.I.; Ansar, S.; Bean, J.; Michaelis, M.L. $\beta$-amyloid and endoplasmic reticulum stress reponses in primary neurons: Effects of drugs that interact with the cytoskeleton. J. Mol. Neurosci. 2006, 28, 111-123. [CrossRef] 
32. Chung, K.M.; Hernández, N.; Sproul, A.A.; Yu, W.H. Alzheimer's disease and the autophagic-lysosomal system. Neurosci. Lett. 2019, 697, 49-58. [CrossRef]

33. Sharma, A.; Smith, H.J.; Yao, P.; Mair, W.B. Causal roles of mitochondrial dynamics in longevity and healthy aging. EMBO Rep. 2019, 20, e48395. [CrossRef]

34. Lane, R.K.; Hilsabeck, T.; Rea, S.L. The role of mitochondrial dysfunction in age-related diseases. Biochim. Biophys. Acta 2015, 1847, 1387-1400. [CrossRef]

35. Lionaki, E.; Markaki, M.; Palikaras, K.; Tavernarakis, N. Mitochondria, autophagy and age-associated neurodegenerative diseases: New insights into a complex interplay. Biochim. Biophys. Acta 2015, 1847, 1412-1423. [CrossRef] [PubMed]

36. Kann, O.; Kovács, R. Mitochondria and neuronal activity. Am. J. Physiol. Cell Physiol. 2007, 292, C641-C657. [CrossRef] [PubMed]

37. Cheng, A.; Hou, Y.; Mattson, M.P. Mitochondria and neuroplasticity. ASN Neuro 2010, 2, 243-256. [CrossRef]

38. Jordán, J.; Ceña, V.; Prehn, J.H.M. Mitochondrial control of neuron death and its role in neurodegenerative disorders. J. Physiol. Biochem. 2003, 59, 129-141. [CrossRef] [PubMed]

39. Empirical Healing among the Alaska Natives. An Historical Perspective-PubMed. Available online: https://pubmed.ncbi.nlm. nih.gov/3078498/ (accessed on 27 December 2020).

40. Stokin, G.B.; Lillo, C.; Falzone, T.L.; Brusch, R.G.; Rockenstein, E.; Mount, S.L.; Raman, R.; Davies, P.; Masliah, E.; Williams, D.S.; et al. Axonopathy and transport deficits early in the pathogenesis of Alzheimer's diseases. Science 2005, 307, 1282-1288. [CrossRef]

41. Wang, X.; Su, B.; Siedlak, S.L.; Moreira, P.I.; Fujioka, H.; Wang, Y.; Casadesus, G.; Zhu, X. Amyloid- $\beta$ overproduction causes abnormal mitochondrial dynamics via differential modulation of mitochondrial fission/fusion proteins. Proc. Natl. Acad. Sci. USA 2008, 105, 19318-19323. [CrossRef]

42. Zaninello, M.; Palikaras, K.; Naon, D.; Iwata, K.; Herkenne, S.; Quintana-Cabrera, R.; Semenzato, M.; Grespi, F.; Ross-Cisneros, F.N.; Carelli, V.; et al. Inhibition of autophagy curtails visual loss in a model of autosomal dominant optic atrophy. Nat. Commun. 2020, 11, 1-12. [CrossRef] [PubMed]

43. Zheng, Y.R.; Zhang, X.N.; Chen, Z. Mitochondrial transport serves as a mitochondrial quality control strategy in axons: Implications for central nervous system disorders. CNS Neurosci. Ther. 2019, 25, 876-886. [CrossRef]

44. Ni, H.M.; Williams, J.A.; Ding, W.X. Mitochondrial dynamics and mitochondrial quality control. Redox Biol. 2015, 4, 6-13. [CrossRef] [PubMed]

45. Gao, J.; Wang, L.; Liu, J.; Xie, F.; Su, B.; Wang, X. Abnormalities of mitochondrial dynamics in neurodegenerative diseases. Antioxidants 2017, 6, 25. [CrossRef]

46. Hroudová, J.; Singh, N.; Fišar, Z. Mitochondrial dysfunctions in neurodegenerative diseases: Relevance to alzheimer's disease. Biomed Res. Int. 2014, 2014, 175062. [CrossRef]

47. Theocharopoulou, G. The ubiquitous role of mitochondria in Parkinson and other neurodegenerative diseases. AIMS Neurosci. 2020, 7, 43-65. [CrossRef]

48. Dessauer, C.W.; Watts, V.J.; Ostrom, R.S.; Conti, M.; Dove, S.; Seifert, R. International union of basic and clinical pharmacology. CI. structures and small molecule modulators of mammalian adenylyl cyclases. Pharmacol. Rev. 2017, 69, 96-139. [CrossRef] [PubMed]

49. Filadi, R.; Basso, E.; Lefkimmiatis, K.; Pozzan, T. Beyond Intracellular Signaling: The Ins and Outs of Second Messengers Microdomains. Adv. Exp. Med. Biol. 2017, 981, 279-322. [PubMed]

50. Halls, M.L.; Cooper, D.M.F. Adenylyl cyclase signalling complexes—Pharmacological challenges and opportunities. Pharmacol. Ther. 2017, 172, 171-180. [CrossRef]

51. Khannpnavar, B.; Mehta, V.; Qi, C.; Korkhov, V. Structure and function of adenylyl cyclases, key enzymes in cellular signaling. Curr. Opin. Struct. Biol. 2020, 63, 34-41. [CrossRef]

52. Tang, W.J.; Gilman, A.G. Adenylyl cyclases. Cell 1992, 70, 869-872. [CrossRef]

53. Steegborn, C.; Litvin, T.N.; Levin, L.R.; Buck, J.; Wu, H. Bicarbonate activation of adenylyl cyclase via promotion of catalytic active site closure and metal recruitment. Nat. Struct. Mol. Biol. 2005, 12, 32-37. [CrossRef] [PubMed]

54. Di Benedetto, G.; Scalzotto, E.; Mongillo, M.; Pozzan, T. Mitochondrial Ca2+ uptake induces cyclic AMP generation in the matrix and modulates organelle ATP levels. Cell Metab. 2013, 17, 965-975. [CrossRef]

55. Hanoune, J.; Defer, N. Regulation and role of adenylyl cyclase isoforms. Annu. Rev. Pharmacol. Toxicol. 2001, 41, 145-174. [CrossRef] [PubMed]

56. Ostrom, R.S.; Bogard, A.S.; Gros, R.; Feldman, R.D. Choreographing the adenylyl cyclase signalosome: Sorting out the partners and the steps. Naunyn. Schmiedebergs. Arch. Pharmacol. 2012, 385, 5-12. [CrossRef]

57. Baillie, G.S. Compartmentalized signalling: Spatial regulation of cAMP by the action of compartmentalized phosphodiesterases. FEBS J. 2009, 276, 1790-1799. [CrossRef] [PubMed]

58. Baillie, G.S.; Scott, J.D.; Houslay, M.D. Compartmentalisation of phosphodiesterases and protein kinase A: Opposites attract. FEBS Lett. 2005, 579, 3264-3270. [CrossRef]

59. Zaccolo, M. CAMP signal transduction in the heart: Understanding spatial control for the development of novel therapeutic strategies. Br. J. Pharmacol. 2009, 158, 50-60. [CrossRef] [PubMed]

60. Zaccolo, M. Spatial control of cAMP signalling in health and disease. Curr. Opin. Pharmacol. 2011, 11, 649-655. [CrossRef] [PubMed] 
61. Yan, C. Cyclic nucleotide phosphodiesterase 1 and vascular aging. Clin. Sci. 2015, 129, 1077-1081. [CrossRef] [PubMed]

62. Jackson, P.K. cAMP Signaling in Nanodomains. Cell 2020, 182, 1379-1381. [CrossRef]

63. Schleicher, K.; Zaccolo, M. Defining a cellular map of cAMP nanodomains. Mol. Pharmacol. 2020. [CrossRef]

64. Brescia, M.; Zaccolo, M. Modulation of compartmentalised cyclic nucleotide signalling via local inhibition of phosphodiesterase activity. Int. J. Mol. Sci. 2016, 17, 1672. [CrossRef]

65. Lomas, O.; Zaccolo, M. Phosphodiesterases maintain signaling fidelity via compartmentalization of cyclic nucleotides. Physiology 2014, 29, 141-149. [CrossRef]

66. Nabavi, S.M.; Talarek, S.; Listos, J.; Nabavi, S.F.; Devi, K.P.; Roberto de Oliveira, M.; Tewari, D.; Argüelles, S.; Mehrzadi, S.; Hosseinzadeh, A.; et al. Phosphodiesterase inhibitors say NO to Alzheimer's disease. Food Chem. Toxicol. 2019, 134, 110822. [CrossRef]

67. Mika, D.; Leroy, J.Ô.; Vandecasteele, G.; Fischmeister, R. PDEs create local domains of cAMP signaling. J. Mol. Cell. Cardiol. 2012, 52, 323-329. [CrossRef] [PubMed]

68. Functional Compartments in Cyclic Nucleotide Action-PubMed. Available online: https://pubmed.ncbi.nlm.nih.gov/6290550/ (accessed on 28 December 2020).

69. Bock, A.; Annibale, P.; Konrad, C.; Hannawacker, A.; Anton, S.E.; Maiellaro, I.; Zabel, U.; Sivaramakrishnan, S.; Falcke, M.; Lohse, M.J. Optical Mapping of cAMP Signaling at the Nanometer Scale. Cell 2020, 182, 1519-1530.e17. [CrossRef]

70. Pendin, D.; Greotti, E.; Lefkimmiatis, K.; Pozzan, T. Exploring cells with targeted biosensors. J. Exp. Physiol. 2017, 149, 1-36. [CrossRef] [PubMed]

71. Zhang, J.Z.; Lu, T.W.; Stolerman, L.M.; Tenner, B.; Yang, J.R.; Zhang, J.F.; Falcke, M.; Rangamani, P.; Taylor, S.S.; Mehta, S.; et al. Phase Separation of a PKA Regulatory Subunit Controls cAMP Compartmentation and Oncogenic Signaling. Cell 2020, 182, 1531-1544.e15. [CrossRef]

72. Lefkimmiatis, K.; Zaccolo, M. CAMP signaling in subcellular compartments. Pharmacol. Ther. 2014, 143, 295-304. [CrossRef] [PubMed]

73. Isobe, K.; Jung, H.J.; Yang, C.-R.; Claxton, J.; Sandoval, P.; Burg, M.B.; Raghuram, V.; Knepper, M.A. Systems-level identification of PKA-dependent signaling in epithelial cells. Proc. Natl. Acad. Sci. USA 2017, 114, E8875-E8884. [CrossRef] [PubMed]

74. Wild, A.R.; Dell'Acqua, M.L. Potential for therapeutic targeting of AKAP signaling complexes in nervous system disorders. Pharmacol. Ther. 2018, 185, 99-121. [CrossRef] [PubMed]

75. Zheng, X.; Krakowiak, J.; Patel, N.; Beyzavi, A.; Ezike, J.; Khalil, A.S.; Pincus, D. Dynamic control of Hsf1 during heat shock by a chaperone switch and phosphorylation. Elife 2016, 5, e18638. [CrossRef]

76. Brini, M.; Calì, T.; Ottolini, D.; Carafoli, E. Neuronal calcium signaling: Function and dysfunction. Cell. Mol. Life Sci. 2014, 71, 2787-2814. [CrossRef]

77. Lefkimmiatis, K. cAMP signalling meets mitochondrial compartments. Biochem. Soc. Trans. 2014, 42, 265-269. [CrossRef]

78. Di Benedetto, G.; Gerbino, A.; Lefkimmiatis, K. Shaping mitochondrial dynamics: The role of cAMP signalling. Biochem. Biophys. Res. Commun. 2017. [CrossRef]

79. Harada, H.; Becknell, B.; Wilm, M.; Mann, M.; Huang, L.J.; Taylor, S.S.; Scott, J.D.; Korsmeyer, S.J. Phosphorylation and inactivation of BAD by mitochondria-anchored protein kinase A. Mol. Cell 1999, 3, 413-422. [CrossRef]

80. Affaitati, A.; Cardone, L.; De Cristofaro, T.; Carlucci, A.; Ginsberg, M.D.; Varrone, S.; Gottesman, M.E.; Avvedimento, E.V.; Feliciello, A. Essential role of A-Kinase anchor protein 121 for cAMP signaling to mitochondria. J. Biol. Chem. 2003, 278, 4286-4294. [CrossRef] [PubMed]

81. Scorziello, A.; Savoia, C.; Sisalli, M.J.; Adornetto, A.; Secondo, A.; Boscia, F.; Esposito, A.; Polishchuk, E.V.; Polishchuk, R.S.; Molinaro, P.; et al. NCX3 regulates mitochondrial $\mathrm{Ca}^{2+}$ handling through the AKAP121-anchored signaling complex and prevents hypoxia-induced neuronal death. J. Cell Sci. 2013, 126, 5566-5577. [CrossRef]

82. Sun, N.; Youle, R.J.; Finkel, T. The Mitochondrial Basis of Aging. Mol. Cell 2016, 61, 654-666. [CrossRef] [PubMed]

83. Ryan, B.J.; Hoek, S.; Fon, E.A.; Wade-Martins, R. Mitochondrial dysfunction and mitophagy in Parkinson's: From familial to sporadic disease. Trends Biochem. Sci. 2015, 40, 200-210. [CrossRef] [PubMed]

84. Khalil, B.; El Fissi, N.; Aouane, A.; Cabirol-Pol, M.J.; Rival, T.; Liévens, J.C. PINK1-induced mitophagy promotes neuroprotection in Huntington's disease. Cell Death Dis. 2015, 6. [CrossRef] [PubMed]

85. Ye, X.; Sun, X.; Starovoytov, V.; Cai, Q. Parkin-mediated mitophagy in mutant hAPP neurons and Alzheimer's disease patient brains. Hum. Mol. Genet. 2015, 24, 2938-2951. [CrossRef]

86. Twig, G.; Elorza, A.; Molina, A.J.A.; Mohamed, H.; Wikstrom, J.D.; Walzer, G.; Stiles, L.; Haigh, S.E.; Katz, S.; Las, G.; et al. Fission and selective fusion govern mitochondrial segregation and elimination by autophagy. EMBO J. 2008, 27, 433-446. [CrossRef]

87. Gomes, L.C.; Di Benedetto, G.; Scorrano, L. During autophagy mitochondria elongate, are spared from degradation and sustain cell viability. Nat. Cell Biol. 2011, 13, 589-598. [CrossRef]

88. Merrill, R.A.; Dagda, R.K.; Dickey, A.S.; Cribbs, J.T.; Green, S.H.; Usachev, Y.M.; Strack, S. Mechanism of neuroprotective mitochondrial remodeling by pka/akap1. PLoS Biol. 2011, 9, e1000612. [CrossRef] [PubMed]

89. Dagda, R.K.; Gusdon, A.M.; Pien, I.; Strack, S.; Green, S.; Li, C.; Van Houten, B.; Cherra, S.J.; Chu, C.T. Mitochondrially localized PKA reverses mitochondrial pathology and dysfunction in a cellular model of Parkinson's disease. Cell Death Differ. 2011, 18, 1914-1923. [CrossRef] [PubMed] 
90. Flippo, K.H.; Gnanasekaran, A.; Perkins, G.A.; Ajmal, A.; Merrill, R.A.; Dickey, A.S.; Taylor, S.S.; McKnight, G.S.; Chauhan, A.K.; Usachev, Y.M.; et al. AKAP1 protects from cerebral ischemic stroke by inhibiting Drp1-dependent mitochondrial fission. J. Neurosci. 2018, 38, 8233-8242. [CrossRef] [PubMed]

91. Miller, K.E.; Sheetz, M.P. Axonal mitochondrial transport and potential are correlated. J. Cell Sci. 2004, 117, 2791-2804. [CrossRef] [PubMed]

92. Akabane, S.; Uno, M.; Tani, N.; Shimazaki, S.; Ebara, N.; Kato, H.; Kosako, H.; Oka, T. PKA Regulates PINK1 Stability and Parkin Recruitment to Damaged Mitochondria through Phosphorylation of MIC60. Mol. Cell 2016, 62, 371-384. [CrossRef]

93. Ogawa, F.; Murphy, L.C.; Malavasi, E.L.V.; O'Sullivan, S.T.; Torrance, H.S.; Porteous, D.J.; Millar, J.K. NDE1 and GSK3 $\beta$ Associate with TRAK1 and Regulate Axonal Mitochondrial Motility: Identification of Cyclic AMP as a Novel Modulator of Axonal Mitochondrial Trafficking. ACS Chem. Neurosci. 2016, 7, 553-564. [CrossRef]

94. Das Banerjee, T.; Dagda, R.Y.; Dagda, M.; Chu, C.T.; Rice, M.; Vazquez-Mayorga, E.; Dagda, R.K. PINK1 regulates mitochondrial trafficking in dendrites of cortical neurons through mitochondrial PKA. J. Neurochem. 2017, 142, 545-559. [CrossRef]

95. Kritzer, M.D.; Li, J.; Dodge-Kafka, K.; Kapiloff, M.S. AKAPs: The Architectural Underpinnings of Local cAMP Signaling. J. Mol. Cell. Cardiol. 2012, 52, 351-358. [CrossRef]

96. Pidoux, G.; Taskén, K. Specificity and spatial dynamics of protein kinase a signaling organized by A-kinase-anchoring proteins. J. Mol. Endocrinol. 2010, 44, 271-284. [CrossRef]

97. Skroblin, P.; Grossmann, S.; Schäfer, G.; Rosenthal, W.; Klussmann, E. Mechanisms of Protein Kinase A Anchoring. In International Review of Cell and Molecular Biology; Elsevier Inc.: Amsterdam, The Netherlands, 2010; Volume 283, pp. $235-330$.

98. Huang, L.J.S.; Durick, K.; Weiner, J.A.; Chun, J.; Taylor, S.S. Identification of a novel protein kinase A anchoring protein that binds both type I and type II regulatory subunits. J. Biol. Chem. 1997, 272, 8057-8064. [CrossRef] [PubMed]

99. Merrill, R.A.; Strack, S. Mitochondria: A kinase anchoring protein 1, a signaling platform for mitochondrial form and function. Int. J. Biochem. Cell Biol. 2014, 48, 92-96. [CrossRef] [PubMed]

100. Czachor, A.; Failla, A.; Lockey, R.; Kolliputi, N. Pivotal role of AKAP121 in mitochondrial physiology. Am. J. Physiol. Cell Physiol. 2016, 310, C625-C628. [CrossRef] [PubMed]

101. Dagda, R.K.; Merrill, R.A.; Cribbs, J.T.; Chen, Y.; Hell, J.W.; Usachev, Y.M.; Strack, S. The spinocerebellar ataxia 12 gene product and protein phosphatase $2 \mathrm{~A}$ regulatory subunit $\mathrm{B} \beta 2$ antagonizes neuronal survival by promoting mitochondrial fission. J. Biol. Chem. 2008, 283, 36241-36248. [CrossRef] [PubMed]

102. Dickey, A.S.; Strack, S. PKA/AKAP1 and PP2A/B 2 Regulate Neuronal Morphogenesis via Drp1 Phosphorylation and Mitochondrial Bioenergetics. J. Neurosci. 2011, 31, 15716-15726. [CrossRef] [PubMed]

103. Liu, Y.; Merrill, R.A.; Strack, S. A-Kinase Anchoring Protein 1: Emerging Roles in Regulating Mitochondrial Form and Function in Health and Disease. Cells 2020, 9, 298. [CrossRef] [PubMed]

104. Jhun, B.S.; O-Uchi, J.; Adaniya, S.M.; Cypress, M.W.; Yoon, Y. Adrenergic regulation of Drp1-driven mitochondrial fission in cardiac physio-pathology. Antioxidants 2018, 7, 195. [CrossRef]

105. Cribbs, J.T.; Strack, S. Reversible phosphorylation of Drp1 by cyclic AMP-dependent protein kinase and calcineurin regulates mitochondrial fission and cell death. EMBO Rep. 2007, 8, 939-944. [CrossRef]

106. Sanderson, J.L.; Gorski, J.A.; Dell'Acqua, M.L. NMDA Receptor-Dependent LTD Requires Transient Synaptic Incorporation of Ca2+-Permeable AMPARs Mediated by AKAP150-Anchored PKA and Calcineurin. Neuron 2016, 89, 1000-1015. [CrossRef]

107. Lu, Y.; Allen, M.; Halt, A.R.; Weisenhaus, M.; Dallapiazza, R.F.; Hall, D.D.; Usachev, Y.M.; McKnight, G.S.; Hell, J.W. Agedependent requirement of AKAP150-anchored PKA and GluR2-lacking AMPA receptors in LTP. EMBO J. 2007, 26, 4879-4890. [CrossRef]

108. Zhang, J.; Shapiro, M.S. Mechanisms and dynamics of AKAP79/150-orchestrated multi-protein signalling complexes in brain and peripheral nerve. J. Physiol. 2016, 594, 31-37. [CrossRef]

109. Sanderson, J.L.; Gorski, J.A.; Gibson, E.S.; Lam, P.; Freund, R.K.; Chick, W.S.; Dell'Acqua, M.L. Akap150-anchored calcineurin regulates synaptic plasticity by limiting synaptic incorporation of Ca2+-permeable AMPA receptors. J. Neurosci. 2012, 32, 15036-15052. [CrossRef] [PubMed]

110. Diering, G.H.; Gustina, A.S.; Huganir, R.L. PKA-GluA1 coupling via AKAP5 controls AMPA receptor phosphorylation and cell-surface targeting during bidirectional homeostatic plasticity. Neuron 2014, 84, 790-805. [CrossRef]

111. Lee, K.F.H.; Soares, C.; Béique, J.C. Tuning into diversity of homeostatic synaptic plasticity. Neuropharmacology $2014,78,31-37$. [CrossRef]

112. Lee, K.Y.; Chung, H.J. NMDA receptors and L-type voltage-gated Ca2+ channels mediate the expression of bidirectional homeostatic intrinsic plasticity in cultured hippocampal neurons. Neuroscience 2014, 277, 610-623. [CrossRef] [PubMed]

113. Lee, H.K.; Takamiya, K.; He, K.; Song, L.; Huganir, R.L. Specific roles of AMPA receptor subunit GluR1 (GluA1) phosphorylation sites in regulating synaptic plasticity in the CA1 region of hippocampus. J. Neurophysiol. 2010, 103, 479-489. [CrossRef]

114. He, K.; Song, L.; Cummings, L.W.; Goldman, J.; Huganir, R.L.; Lee, H.K. Stabilization of Ca2+-permeable AMPA receptors at perisynaptic sites by GluR1-S845 phosphorylation. Proc. Natl. Acad. Sci. USA 2009, 106, 20033-20038. [CrossRef]

115. Malenka, R.C.; Bear, M.F. LTP and LTD: An embarrassment of riches. Neuron 2004, 44, 5-21. [CrossRef]

116. Dell'Acqua, M.L.; Faux, M.C.; Thorburn, J.; Thorburn, A.; Scott, J.D. Membrane-targeting sequences on AKAP79 bind phosphatidylinositol-4,5-bisphosphate. EMBO J. 1998, 17, 2246-2260. [CrossRef] [PubMed] 
117. Gorski, J.A.; Gomez, L.L.; Scott, J.D.; Dell'Acqua, M.L. Association of an A-kinase-anchoring protein signaling scaffold with cadherin adhesion molecules in neurons and epithelial cells. Mol. Biol. Cell 2005, 16, 3574-3590. [CrossRef]

118. Gomez, L.L.; Alam, S.; Smith, K.E.; Horne, E.; Dell'Acqua, M.L. Regulation of A-kinase anchoring protein 79/150-cAMPdependent protein kinase postsynaptic targeting by NMDA receptor activation of calcineurin and remodeling of dendritic actin. J. Neurosci. 2002, 22, 7027-7044. [CrossRef]

119. Nikandrova, Y.A.; Jiao, Y.; Baucum, A.J.; Tavalin, S.J.; Colhran, R.J. Ca2+/calmodulin-dependent protein kinase II binds to and phosphorylates a specific SAP97 splice variant to disrupt association with AKAP79/150 and modulate $\alpha$-amino-3-hydroxy5-methyl-4-isoxazolepropionic acid-type glutamate receptor (AMPAR) activity. J. Biol. Chem. 2010, 285, 923-934. [CrossRef] [PubMed]

120. Colledge, M.; Dean, R.A.; Scott, G.K.; Langeberg, L.K.; Huganir, R.L.; Scott, J.D. Targeting of PKA to glutamate receptors through a MAGUK-AKAP complex. Neuron 2000, 27, 107-119. [CrossRef]

121. Robertson, H.R.; Gibson, E.S.; Benke, T.A.; Dell'Acqua, M.L. Regulation of postsynaptic structure and function by an A-kinase anchoring protein-membrane-associated guanylate kinase scaffolding complex. J. Neurosci. 2009, 29, 7929-7943. [CrossRef] [PubMed]

122. Pallafacchina, G.; Zanin, S.; Rizzuto, R. Recent advances in the molecular mechanism of mitochondrial calcium uptake. F1000Research 2018, 7, 1858. [CrossRef]

123. Pizzo, P.; Lissandron, V.; Capitanio, P.; Pozzan, T. Ca ${ }^{2+}$ signalling in the Golgi apparatus. Cell Calcium 2011, 50, 184-192. [CrossRef]

124. Patel, S.; Cai, X. Evolution of acidic $\mathrm{Ca}^{2+}$ stores and their resident $\mathrm{Ca}^{2+}$-permeable channels. Cell Calcium 2015, 57, 222-230. [CrossRef]

125. Giorgi, C.; Danese, A.; Missiroli, S.; Patergnani, S.; Pinton, P. Calcium Dynamics as a Machine for Decoding Signals. Trends Cell Biol. 2018, 28, 258-273. [CrossRef] [PubMed]

126. Mougenot, N.; Mika, D.; Czibik, G.; Marcos, E.; Abid, S.; Houssaini, A.; Vallin, B.; Guellich, A.; Mehel, H.; Sawaki, D.; et al. Cardiac adenylyl cyclase overexpression precipitates and aggravates age-related myocardial dysfunction. Cardiovasc. Res. 2019, 115, 1778-1790. [CrossRef]

127. Ferrara, N.; Komici, K.; Corbi, G.; Pagano, G.; Furgi, G.; Rengo, C.; Femminella, G.D.; Leosco, D.; Bonaduce, D. $\beta$-adrenergic receptor responsiveness in aging heart and clinical implications. Front. Physiol. 2014, 4, 396. [CrossRef]

128. Strait, J.B.; Lakatta, E.G. Aging-Associated Cardiovascular Changes and Their Relationship to Heart Failure. Heart Fail. Clin. 2012, 8, 143-164. [CrossRef]

129. Shioi, T.; Inuzuka, Y. Aging as a substrate of heart failure. J. Cardiol. 2012, 60, 423-428. [CrossRef] [PubMed]

130. Cerbai, E.; Guerra, L.; Varani, K.; Barbieri, M.; Borea, P.A.; Mugelli, A. $\beta$-Adrenoceptor subtypes in young and old rat ventricular myocytes: A combined patch-clamp and binding study. Br. J. Pharmacol. 1995, 116, 1835-1842. [CrossRef]

131. Leineweber, K.; Klapproth, S.; Beilfuß, A.; Silber, R.E.; Heusch, G.; Philipp, T.; Brodde, O.E. Unchanged G-Protein-Coupled Receptor Kinase Activity in the Aging Human Heart. J. Am. Coll. Cardiol. 2003, 42, 1487-1492. [CrossRef]

132. Schutzer, W.E.; Reed, J.F.; Bliziotes, M.; Mader, S.L. Upregulation of G protein-linked receptor kinases with advancing age in rat aorta. Am. J. Physiol. Regul. Integr. Comp. Physiol. 2001, 280, R897-R903. [CrossRef]

133. Rengo, G.; Perrone-Filardi, P.; Femminella, G.D.; Liccardo, D.; Zincarelli, C.; De Lucia, C.; Pagano, G.; Marsico, F.; Lymperopoulos, A.; Leosco, D. Targeting the $\beta$-adrenergic receptor system through g-protein-coupled receptor kinase 2: A new paradigm for therapy and prognostic evaluation in heart failure from bench to bedside giuseppe rengo pasquale perrone-filardi. Circ. Hear. Fail. 2012, 5, 385-391. [CrossRef] [PubMed]

134. Rengo, G.; Galasso, G.; Femminella, G.D.; Parisi, V.; Zincarelli, C.; Pagano, G.; de Lucia, C.; Cannavo, A.; Liccardo, D.; Marciano, C.; et al. Reduction of lymphocyte G protein-coupled receptor kinase-2 (GRK2) after exercise training predicts survival in patients with heart failure. Eur. J. Prev. Cardiol. 2014, 21, 4-11. [CrossRef] [PubMed]

135. Cohn, J.N.; Ferrari, R.; Sharpe, N. Cardiac remodeling-concepts and clinical implications: A consensus paper from an International Forum on Cardiac Remodeling. J. Am. Coll. Cardiol. 2000, 35, 569-582. [CrossRef]

136. Singh, K.; Communal, C.; Sawyer, D.B.; Colucci, W.S. Adrenergic regulation of myocardial apoptosis. Cardiovasc. Res. 2000, 45, 713-719. [CrossRef]

137. Santulli, G.; Iaccarino, G. Adrenergic signaling in heart failure and cardiovascular aging. Maturitas 2016, 93, 65-72. [CrossRef]

138. Xu, X.; Wang, D.W. The progress and controversial of the use of beta blockers in patients with heart failure with a preserved ejection fraction. IJC Heart Vasc. 2020, 26, 100451. [CrossRef]

139. Esposito, G.; Perrino, C.; Ozaki, T.; Takaoka, H.; Defer, N.; Petretta, M.P.; De Angelis, M.C.; Mao, L.; Hanoune, J.; Rockman, H.A.; et al. Increased myocardial contractility and enhanced exercise function in transgenic mice overexpressing either adenylyl cyclase 5 or 8. Basic Res. Cardiol. 2008, 103, 22-30. [CrossRef] [PubMed]

140. Vatner, S.F.; Pachon, R.E.; Vatner, D.E. Inhibition of adenylyl cyclase type 5 increases longevity and healthful aging through oxidative stress protection. Oxid. Med. Cell. Longev. 2015, 2015, 250310. [CrossRef] [PubMed]

141. Lai, L.; Yan, L.; Gao, S.; Hu, C.L.; Ge, H.; Davidow, A.; Park, M.; Bravo, C.; Iwatsubo, K.; Ishikawa, Y.; et al. Type 5 adenylyl cyclase increases oxidative stress by transcriptional regulation of manganese superoxide dismutase via the SIRT1/FoxO3a pathway. Circulation 2013, 127, 1692-1701. [CrossRef] [PubMed]

142. Vatner, D.E.; Yan, L.; Lai, L.; Yuan, C.; Mouchiroud, L.; Pachon, R.E.; Zhang, J.; Dillinger, J.G.; Houtkooper, R.H.; Auwerx, J.; et al. Type 5 adenylyl cyclase disruption leads to enhanced exercise performance. Aging Cell 2015, 14, 1075-1084. [CrossRef] 
143. Okumura, S.; Takagi, G.; Kawabe, J.I.; Yang, G.; Lee, M.C.; Hong, C.; Liu, J.; Vatner, D.E.; Sadoshima, J.; Vatner, S.F.; et al. Disruption of type 5 adenylyl cyclase gene preserves cardiac function against pressure overload. Proc. Natl. Acad. Sci. USA 2003, 100, 9986-9990. [CrossRef]

144. Okumura, S.; Vatner, D.E.; Kurotani, R.; Bai, Y.; Gao, S.; Yuan, Z.; Iwatsubo, K.; Ulucan, C.; Kawabe, J.I.; Ghosh, K.; et al. Disruption of type 5 adenylyl cyclase enhances desensitization of cyclic adenosine monophosphate signal and increases Akt signal with chronic catecholamine stress. Circulation 2007, 116, 1776-1783. [CrossRef]

145. Yan, L.; Vatner, D.E.; O'Connor, J.P.; Ivessa, A.; Ge, H.; Chen, W.; Hirotani, S.; Ishikawa, Y.; Sadoshima, J.; Vatner, S.F. Type 5 Adenylyl Cyclase Disruption Increases Longevity and Protects Against Stress. Cell 2007, 130, 247-258. [CrossRef]

146. Yan, L.; Vatner, S.F.; Vatner, D.E. Disruption of type 5 adenylyl cyclase prevents $\beta$-adrenergic receptor cardiomyopathy: A novel approach to $\beta$-adrenergic receptor blockade. Am. J. Physiol. Heart Circ. Physiol. 2014, 307, H1521-H1528. [CrossRef]

147. Yan, L.; Park, J.Y.; Dillinger, J.G.; De Lorenzo, M.S.; Yuan, C.; Lai, L.; Wang, C.; Ho, D.; Tian, B.; Stanley, W.C.; et al. Common mechanisms for calorie restriction and adenylyl cyclase type 5 knockout models of longevity. Aging Cell 2012, 11, 1110-1120. [CrossRef] [PubMed]

148. Guers, J.J.; Zhang, J.; Campbell, S.C.; Oydanich, M.; Vatner, D.E.; Vatner, S.F. Disruption of adenylyl cyclase type 5 mimics exercise training. Basic Res. Cardiol. 2017, 112. [CrossRef]

149. De Lorenzo, M.S.; Chen, W.; Baljinnyam, E.; Carlini, M.J.; La Perle, K.; Bishop, S.P.; Wagner, T.E.; Rabson, A.B.; Vatner, D.E.; Puricelli, L.I.; et al. Reduced malignancy as a mechanism for longevity in mice with adenylyl cyclase type 5 disruption. Aging Cell 2014, 13, 102-110. [CrossRef] [PubMed]

150. Beazely, M.A.; Watts, V.J. Regulatory properties of adenylate cyclases type 5 and 6: A progress report. Eur. J. Pharmacol. 2006, 535, 1-12. [CrossRef]

151. Cosson, M.V.; Hiis, H.G.; Moltzau, L.R.; Levy, F.O.; Krobert, K.A. Knockout of adenylyl cyclase isoform 5 or 6 differentially modifies the $\beta 1$-adrenoceptor-mediated inotropic response. J. Mol. Cell. Cardiol. 2019, 131, 132-145. [CrossRef]

152. Tang, T.; Lai, N.C.; Hammond, H.K.; Roth, D.M.; Yang, Y.; Guo, T.; Gao, M.H. Adenylyl Cyclase 6 Deletion Reduces Left Ventricular Hypertrophy, Dilation, Dysfunction, and Fibrosis in Pressure-Overloaded Female Mice. J. Am. Coll. Cardiol. 2010, 55, 1476-1486. [CrossRef] [PubMed]

153. Tang, T.; Gao, M.H.; Lai, N.C.; Firth, A.L.; Takahashi, T.; Guo, T.; Yuan, J.X.J.; Roth, D.M.; Hammond, H.K. Adenylyl cyclase type 6 deletion decreases left ventricular function via impaired calcium handling. Circulation 2008, 117, 61-69. [CrossRef]

154. Roth, D.M.; Bayat, H.; Drumm, J.D.; Gao, M.H.; Swaney, J.S.; Ander, A.; Hammond, H.K. Adenylyl cyclase increases survival in cardiomyopathy. Circulation 2002, 105, 1989-1994. [CrossRef] [PubMed]

155. Lai, N.C.; Roth, D.M.; Gao, M.H.; Tang, T.; Dalton, N.; Lai, Y.Y.; Spellman, M.; Clopton, P.; Hammond, K.K. Intracoronary adenovirus encoding adenylyl cyclase VI increases left ventricular function in heart failure. Circulation 2004, 110, 330-336. [CrossRef]

156. Takahashi, T.; Tang, T.; Lai, N.C.; Roth, D.M.; Rebolledo, B.; Saito, M.; Lew, W.Y.W.; Clopton, P.; Hammond, H.K. Increased cardiac adenylyl cyclase expression is associated with increased survival after myocardial infarction. Circulation 2006, 114, 388-396. [CrossRef] [PubMed]

157. Lai, N.C.; Tang, T.; Gao, M.H.; Saito, M.; Takahashi, T.; Roth, D.M.; Hammond, H.K. Activation of Cardiac Adenylyl Cyclase Expression Increases Function of the Failing Ischemic Heart in Mice. J. Am. Coll. Cardiol. 2008, 51, 1490-1497. [CrossRef] [PubMed]

158. Guellich, A.; Gao, S.; Hong, C.; Yan, L.; Wagner, T.E.; Dhar, S.K.; Ghaleh, B.; Hittinger, L.; Iwatsubo, K.; Ishikawa, Y.; et al. Effects of cardiac overexpression of type 6 adenylyl cyclase affects on the response to chronic pressure overload. Am. J. Physiol. Heart Circ. Physiol. 2010, 299. [CrossRef] [PubMed]

159. Ostrom, R.S.; Liu, X.; Head, B.P.; Gregorian, C.; Seasholtz, T.M.; Insel, P.A. Localization of adenylyl cyclase isoforms and G protein-coupled receptors in vascular smooth muscle cells: Expression in caveolin-rich and noncaveolin domains. Mol. Pharmacol. 2002, 62, 983-992. [CrossRef]

160. Saeed, S.; Bonnefond, A.; Tamanini, F.; Mirza, M.U.; Manzoor, J.; Janjua, Q.M.; Din, S.M.; Gaitan, J.; Milochau, A.; Durand, E.; et al. Loss-of-function mutations in ADCY3 cause monogenic severe obesity. Nat. Genet. 2018, 50, 175-179. [CrossRef] [PubMed]

161. Age Associated Changes in Intracellular Cyclic Adenosine Monophosphate-PubMed. Available online: https://pubmed.ncbi. nlm.nih.gov/6323074/ (accessed on 28 December 2020).

162. Alterations in Cyclic Nucleotides and Cyclase-Specific Activities in T Lymphocytes of Aging Normal Humans and Patients with Down's Syndrome-PubMed. Available online: https:/ / pubmed.ncbi.nlm.nih.gov/6106029/ (accessed on 28 December 2020).

163. Puri, S.K.; Volicer, L. Age-related changes of cyclic nucleotide levels in rat brain regions. Mech. Ageing Dev. 1981, 15, $239-242$. [CrossRef]

164. Puri, S.K.; Volicer, L. Effect of aging on cyclic AMP levels and adenylate cyclase and phosphodiesterase activities in the rat corpus striatum. Mech. Ageing Dev. 1977, 6, 53-58. [CrossRef]

165. Cowburn, R.F.; O’Neill, C.; Ravid, R.; Alafuzoff, I.; Winblad, B.; Fowler, C.J. Adenylyl Cyclase Activity in Postmortem Human Brain: Evidence of Altered G Protein Mediation in Alzheimer's Disease. J. Neurochem. 1992, 58, 1409-1419. [CrossRef]

166. Cowburn, R.F.; O’Neill, C.; Ravid, R.; Winblad, B.; Fowler, C.J. Preservation of Gi-protein inhibited adenylyl cyclase activity in the brains of patients with Alzheimer's disease. Neurosci. Lett. 1992, 141, 16-20. [CrossRef] 
167. Sugawa, M.; May, T. Age-related alteration in signal transduction: Involvement of the cAMP cascade. Brain Res. 1993, 618, 57-62. [CrossRef]

168. Makman, M.H.; Ahn, H.S.; Thal, L.J.; Dvorkin, B.; Horowitz, S.G.; Sharpless, N.S.; Rosenfeld, M. Biogenic amine-stimulated adenylate cyclase and spiroperidol-binding sites in rabbit brain: Evidence for selective loss of receptors with aging. Adv. Exp. Med. Biol. 1978, 113, 211-230. [CrossRef]

169. Makman, M.H.; Ahn, H.S.; Thal, L.J.; Sharpless, N.S.; Dvorkin, B.; Horowitz, S.G.; Rosenfeld, M. Evidence for selective loss of brain dopamine- and histamine-stimulated adenylate cyclase activities in rabbits with aging. Brain Res. 1980, 192, 177-183. [CrossRef]

170. Araki, T.; Kato, H.; Fujiwara, T.; Itoyama, Y. Age-related changes in bindings of second messengers in the rat brain. Brain Res. 1995, 704, 227-232. [CrossRef]

171. Ohadi, D.; Schmitt, D.L.; Calabrese, B.; Halpain, S.; Zhang, J.; Rangamani, P. Computational Modeling Reveals Frequency Modulation of Calcium-cAMP/PKA Pathway in Dendritic Spines. Biophys. J. 2019, 117, 1963-1980. [CrossRef] [PubMed]

172. Batty, N.J.; Fenrich, K.K.; Fouad, K. The role of cAMP and its downstream targets in neurite growth in the adult nervous system. Neurosci. Lett. 2017, 652, 56-63. [CrossRef]

173. Garelick, M.G.; Chan, G.C.K.; DiRocco, D.P.; Storm, D.R. Overexpression of type I adenylyl cyclase in the forebrain impairs spatial memory in aged but not young mice. J. Neurosci. 2009, 29, 10835-10842. [CrossRef] [PubMed]

174. Yamamoto, M.; Götz, M.E.; Ozawa, H.; Luckhaus, C.; Saito, T.; Rösler, M.; Riederer, P. Hippocampal level of neural specific adenylyl cyclase type I is decreased in Alzheimer's disease. Biochim. Biophys. Acta Mol. Basis Dis. 2000, 1535, 60-68. [CrossRef]

175. Kelly, M.P.; Adamowicz, W.; Bove, S.; Hartman, A.J.; Mariga, A.; Pathak, G.; Reinhart, V.; Romegialli, A.; Kleiman, R.J. Select 3',5'-cyclic nucleotide phosphodiesterases exhibit altered expression in the aged rodent brain. Cell. Signal. 2014, 26, 383-397. [CrossRef]

176. Paspalas, C.D.; Wang, M.; Arnsten, A.F.T. Constellation of HCN channels and cAMP regulating proteins in dendritic spines of the primate prefrontal cortex: Potential substrate for working memory deficits in schizophrenia. Cereb. Cortex 2013, 23, $1643-1654$. [CrossRef]

177. Carlyle, B.C.; Nairn, A.C.; Wang, M.; Yang, Y.; Jin, L.E.; Simen, A.A.; Ramos, B.P.; Bordner, K.A.; Craft, G.E.; Davies, P.; et al. cAMP-PKA phosphorylation of tau confers risk for degeneration in aging association cortex. Proc. Natl. Acad. Sci. USA 2014, 111, 5036-5041. [CrossRef]

178. Ramos, B.P.; Birnbaum, S.G.; Lindenmayer, I.; Newton, S.S.; Duman, R.S.; Arnsten, A.F.T. Dysregulation of protein kinase A signaling in the aged prefrontal cortex: New strategy for treating age-related cognitive decline. Neuron 2003, 40, 835-845. [CrossRef]

179. Citri, A.; Malenka, R.C. Synaptic plasticity: Multiple forms, functions, and mechanisms. Neuropsychopharmacology $2008,33,18-41$. [CrossRef] [PubMed]

180. Bartsch, D.; Casadio, A.; Karl, K.A.; Serodio, P.; Kandel, E.R. CREB1 encodes a nuclear activator, a repressor, and a cytoplasmic modulator that form a regulatory unit critical for long-term facilitation. Cell 1998, 95, 211-223. [CrossRef]

181. Alberini, C.M.; Kandel, E.R. The regulation of transcription in memory consolidation. Cold Spring Harb. Perspect. Biol. 2015, 7, a021741. [CrossRef] [PubMed]

182. Ortega-Martínez, S. A new perspective on the role of the CREB family of transcription factors in memory consolidation via adult hippocampal neurogenesis. Front. Mol. Neurosci. 2015, 8, 46. [CrossRef]

183. Kandel, E.R. The molecular biology of memory: CAMP, PKA, CRE, CREB-1, CREB-2, and CPEB. Mol. Brain 2012, 5, 1-12. [CrossRef]

184. Bach, M.E.; Barad, M.; Son, H.; Zhuo, M.; Lu, Y.F.; Shih, R.; Mansuy, I.; Hawkins, R.D.; Kandel, E.R. Age-related defects in spatial memory are correlated with defects in the late phase of hippocampal long-term potentiation in vitro and are attenuated by drugs that enhance the cAMP signaling pathway. Proc. Natl. Acad. Sci. USA 1999, 96, 5280-5285. [CrossRef] [PubMed]

185. Porte, Y.; Buhot, M.C.; Mons, N. Alteration of CREB phosphorylation and spatial memory deficits in aged 129T2/Sv mice. Neurobiol. Aging 2008, 29, 1533-1546. [CrossRef] [PubMed]

186. Kirschner, L.S.; Yin, Z.; Jones, G.N.; Mahoney, E. Mouse models of altered protein kinase A signaling. Endocr. Relat. Cancer 2009, 16, 773-793. [CrossRef]

187. Skålhegg, B.S.; Huang, Y.; Su, T.; Idzerda, R.L.; McKnight, G.S.; Burton, K.A. Mutation of the C $\alpha$ Subunit of PKA Leads to Growth Retardation and Sperm Dysfunction. Mol. Endocrinol. 2002, 16, 630-639. [CrossRef]

188. Oksvold, M.P.; Funderud, A.; Kvissel, A.K.; Skarpen, E.; Henanger, H.; Huitfeldt, H.S.; Skålhegg, B.S.; Ørstavik, S. Epidermal growth factor receptor levels are reduced in mice with targeted disruption of the protein kinase A catalytic subunit. BMC Cell Biol. 2008, 9, 1-9. [CrossRef]

189. Howe, D.G.; Wiley, J.C.; McKnight, G.S. Molecular and behavioral effects of a null mutation in all PKA C $\beta$ isoforms. Mol. Cell. Neurosci. 2002, 20, 515-524. [CrossRef]

190. Enns, L.C.; Morton, J.F.; Treuting, P.R.; Emond, M.J.; Wolf, N.S.; McKnight, G.S.; Rabinovitch, P.S.; Ladiges, W.C. Disruption of protein kinase A in mice enhances healthy aging. PLoS ONE 2009, 4, e5963. [CrossRef] [PubMed]

191. London, E.; Noguchi, A.; Springer, D.; Faidas, M.; Gavrilova, O.; Eisenhofer, G.; Stratakis, C.A. The Catalytic Subunit $\beta$ of PKA Affects Energy Balance and Catecholaminergic Activity. J. Endocr. Soc. 2019, 3, 1062-1078. [CrossRef]

192. Enns, L.C.; Ladiges, W. Protein kinase A signaling as an anti-aging target. Ageing Res. Rev. 2010, 9, 269-272. [CrossRef] [PubMed] 
193. Zhang, X.; Szeto, C.; Gao, E.; Tang, M.; Jin, J.; Fu, Q.; Makarewich, C.; Ai, X.; Li, Y.; Tang, A.; et al. Cardiotoxic and cardioprotective features of chronic $\beta$-Adrenergic signaling. Circ. Res. 2013, 112, 498-509. [CrossRef] [PubMed]

194. Khaliulin, I.; Parker, J.E.; Halestrap, A.P. Consecutive pharmacological activation of PKA and PKC mimics the potent cardioprotection of temperature preconditioning. Cardiovasc. Res. 2010, 88, 324-333. [CrossRef]

195. Amieux, P.S.; Howe, D.G.; Knickerbocker, H.; Lee, D.C.; Su, T.; Laszlo, G.S.; Idzerda, R.L.; Stanley McKnight, G. Increased basal cAMP-dependent protein kinase activity inhibits the formation of mesoderm-derived structures in the developing mouse embryo. J. Biol. Chem. 2002, 277, 27294-27304. [CrossRef]

196. London, E.; Nesterova, M.; Sinaii, N.; Szarek, E.; Chanturiya, T.; Mastroyannis, S.A.; Gavrilova, O.; Stratakis, C.A. Differentially regulated protein kinase A (PKA) activity in adipose tissue and liver is associated with resistance to diet-induced obesity and glucose intolerance in mice that lack PKA regulatory subunit type II $\alpha$. Endocrinology 2014, 155, 3397-3408. [CrossRef]

197. Cummings, D.E.; Brandon, E.P.; Planas, J.V.; Motamed, K.; Idzerda, R.L.; McKnight, G.S. Genetically lean mice result from targeted disruption of the RII $\beta$ subunit of protein kinase A. Nature 1996, 382, 622-626. [CrossRef] [PubMed]

198. Schreyer, S.A.; Cummings, D.E.; McKnight, G.S.; LeBoeuf, R.C. Mutation of the RII $\beta$ Subunit of Protein Kinase A Prevents Diet-Induced Insulin Resistance and Dyslipidemia in Mice. Diabetes 2001, 50, 2555-2562. [CrossRef]

199. Planas, J.V.; Cummings, D.E.; Idzerda, R.L.; McKnight, G.S. Mutation of the RII $\beta$ subunit of protein kinase A differentially affects lipolysis but not gene induction in white adipose tissue. J. Biol. Chem. 1999, 274, 36281-36287. [CrossRef]

200. Lin, S.J.; Defossez, P.A.; Guarente, L. Requirement of NAD and SIR2 for life-span extension by calorie restriction in saccharomyces cerevisiae. Science 2000, 289, 2126-2128. [CrossRef] [PubMed]

201. Dehghan, E.; Goodarzi, M.; Saremi, B.; Lin, R.; Mirzaei, H. Hydralazine targets cAMP-dependent protein kinase leading to sirtuin $1 / 5$ activation and lifespan extension in C. elegans. Nat. Commun. 2019, 10,1-16. [CrossRef]

202. Tong, J.J.; Schriner, S.E.; McCleary, D.; Day, B.J.; Wallace, D.C. Life extension through neurofibromin mitochondrial regulation and antioxidant therapy for neurofibromatosis-1 in Drosophila melanogaster. Nat. Genet. 2007, 39, 476-485. [CrossRef]

203. Rababa'h, A.; Singh, S.; Suryavanshi, S.V.; Altarabsheh, S.E.; Deo, S.V.; McConnell, B.K. Compartmentalization role of A-kinase anchoring proteins (AKAPs) in Mediating protein kinase A (PKA) signaling and Cardiomyocyte Hypertrophy. Int. J. Mol. Sci. 2014, 16, 218-229. [CrossRef] [PubMed]

204. Dema, A.; Perets, E.; Schulz, M.S.; Deák, V.A.; Klussmann, E. Pharmacological targeting of AKAP-directed compartmentalized cAMP signalling. Cell. Signal. 2015, 27, 2474-2487. [CrossRef]

205. Qian, H.; Matt, L.; Zhang, M.; Nguyen, M.; Patriarchi, T.; Koval, O.M.; Anderson, M.E.; He, K.; Lee, H.K.; Hell, J.W. $\beta 2$-adrenergic receptor supports prolonged theta tetanus-induced LTP. J. Neurophysiol. 2012, 107, 2703-2712. [CrossRef] [PubMed]

206. Zhang, M.; Patriarchi, T.; Stein, I.S.; Qian, H.; Matt, L.; Nguyen, M.; Xiang, Y.K.; Hell, J.W. Adenylyl cyclase anchoring by a kinase anchor protein AKAP5 (AKAP79/150) is important for postsynaptic $\beta$-adrenergic signaling. J. Biol. Chem. 2013, 288, 17918-17931. [CrossRef] [PubMed]

207. Qian, H.; Patriarchi, T.; Price, J.L.; Matt, L.; Lee, B.; Nieves-Cintrón, M.; Buonarati, O.R.; Chowdhury, D.; Nanou, E.; Nystoriak, M.A.; et al. Phosphorylation of Ser1928 mediates the enhanced activity of the L-type Ca2+ channel Cav1.2 by the $\beta 2$-adrenergic receptor in neurons. Sci. Signal. 2017, 10. [CrossRef]

208. Moosmang, S.; Haider, N.; Klugbauer, N.; Adelsberger, H.; Langwieser, N.; Müller, J.; Stiess, M.; Marais, E.; Schulla, V.; Lacinova, L.; et al. Role of hippocampal Cav1.2 Ca2+ channels in NMDA receptor-independent synaptic plasticity and spatial memory. $J$. Neurosci. 2005, 25, 9883-9892. [CrossRef] [PubMed]

209. Patriarchi, T.; Buonarati, O.R.; Hell, J.W. Postsynaptic localization and regulation of AMPA receptors and Cav1.2 by $\beta 2$ adrenergic receptor/PKA and Ca 2+ /CaMKII signaling. EMBO J. 2018, 37. [CrossRef] [PubMed]

210. Oliveria, S.F.; Dell'Acqua, M.L.; Sather, W.A. AKAP79/150 Anchoring of Calcineurin Controls Neuronal L-Type Ca2+ Channel Activity and Nuclear Signaling. Neuron 2007, 55, 261-275. [CrossRef]

211. Dittmer, P.J.; Dell'Acqua, M.L.; Sather, W.A. Ca2+/calcineurin-dependent inactivation of neuronal L-Type Ca2+ channels requires priming by AKAP-anchored protein kinase A. Cell Rep. 2014, 7, 1410-1416. [CrossRef]

212. Oliveria, S.F.; Dittmer, P.J.; Ho Youn, D.; dell'Acqua, M.L.; Sather, W.A. Localized calcineurin confers Ca2+-dependent inactivation on neuronal L-type Ca2+ channels. J. Neurosci. 2012, 32, 15328-15337. [CrossRef] [PubMed]

213. Murphy, J.G.; Sanderson, J.L.; Gorski, J.A.; Scott, J.D.; Catterall, W.A.; Sather, W.A.; Dell'Acqua, M.L. AKAP-anchored PKA maintains neuronal L-type calcium channel activity and NFAT transcriptional signaling. Cell Rep. 2014, 7, 1577-1588. [CrossRef]

214. Weisenhaus, M.; Allen, M.L.; Yang, L.; Lu, Y.; Nichols, C.B.; Su, T.; Hell, J.W.; Mcknight, G.S. Mutations in AKAP5 disrupt dendritic signaling complexes and lead to electrophysiological and behavioral phenotypes in mice. PLoS ONE 2010, 5, e10325. [CrossRef]

215. Jurado, S. AMPA receptor trafficking in natural and pathological aging. Front. Mol. Neurosci. 2018, 10, 446. [CrossRef] [PubMed]

216. Thiagarajan, T.C.; Piedras-Renteria, E.S.; Tsien, R.W. $\alpha$ - and $\beta$ CaMKII: Inverse regulation by neuronal activity and opposing effects on synaptic strength. Neuron 2002, 36, 1103-1114. [CrossRef]

217. Thiagarajan, T.C.; Lindskog, M.; Tsien, R.W. Adaptation to synaptic inactivity in hippocampal neurons. Neuron 2005, $47,725-737$. [CrossRef]

218. Groth, R.D.; Lindskog, M.; Thiagarajan, T.C.; Li, L.; Tsien, R.W. $\beta$ Ca2+/CaM-dependent kinase type II triggers upregulation of GluA1 to coordinate adaptation to synaptic inactivity in hippocampal neurons. Proc. Natl. Acad. Sci. USA 2011, 108, 828-833. [CrossRef] 
219. Kim, S.; Ziff, E.B. Calcineurin Mediates Synaptic Scaling Via Synaptic Trafficking of Ca2+-Permeable AMPA Receptors. PLoS Biol. 2014, 12, 1-15. [CrossRef]

220. Soderling, T.R.; Derkach, V.A. Postsynaptic protein phosphorylation and LTP. Trends Neurosci. 2000, 23, 75-80. [CrossRef]

221. Ortner, N.J.; Striessnig, J. L-type calcium channels as drug targets in CNS disorders. Channels 2016, 10, 7-13. [CrossRef]

222. Buchholz, J.N.; Behringer, E.J.; Pottorf, W.J.; Pearce, W.J.; Vanterpool, C.K. Age-dependent changes in Ca2+ homeostasis in peripheral neurones: Implications for changes in function. Aging Cell 2007, 6, 285-296. [CrossRef]

223. Murchison, D.; Griffith, W.H. Calcium buffering systems and calcium signaling in aged rat basal forebrain neurons. Aging Cell 2007, 6, 297-305. [CrossRef]

224. Griffith, W.H.; DuBois, D.W.; Fincher, A.; Peebles, K.A.; Bizon, J.L.; Murchison, D. Characterization of age-related changes in synaptic transmission onto F344 rat basal forebrain cholinergic neurons using a reduced synaptic preparation. J. Neurophysiol. 2014. [CrossRef]

225. Calvo-Rodriguez, M.; Hernando-Perez, E.; Nuñez, L.; Villalobos, C. Amyloid $\beta$ oligomers increase ER-mitochondria Ca2+ cross talk in young hippocampal neurons and exacerbate aging-induced intracellular Ca2+ remodeling. Front. Cell. Neurosci. 2019, 13, 1-18. [CrossRef] [PubMed]

226. Calvo-Rodríguez, M.; García-Durillo, M.; Villalobos, C.; Núñez, L. In vitro aging promotes endoplasmic reticulum (ER)mitochondria $\mathrm{Ca}^{2+}$ cross talk and loss of store-operated $\mathrm{Ca}^{2+}$ entry (SOCE) in rat hippocampal neurons. Biochim. Biophys. Acta Mol. Cell Res. 2016, 1863, 2637-2649. [CrossRef]

227. Calvo-Rodriguez, M.; Hernando-Pérez, E.; López-Vázquez, S.; Núñez, J.; Villalobos, C.; Núñez, L. Remodeling of intracellular $\mathrm{Ca} 2+$ homeostasis in rat hippocampal neurons aged in vitro. Int. J. Mol. Sci. 2020, 21, 1549. [CrossRef]

228. Pandya, J.D.; Grondin, R.; Yonutas, H.M.; Haghnazar, H.; Gash, D.M.; Zhang, Z.; Sullivan, P.G. Decreased mitochondrial bioenergetics and calcium buffering capacity in the basal ganglia correlates with motor deficits in anonhuman primate model of aging. Neurobiol. Aging 2015. [CrossRef] [PubMed]

229. Pereda, D.; Al-Osta, I.; Okorocha, A.E.; Easton, A.; Hartell, N.A. Changes in presynaptic calcium signalling accompany age-related deficits in hippocampal LTP and cognitive impairment. Aging Cell 2019, 18, 1-11. [CrossRef]

230. Gant, J.C.; Chen, K.C.; Norris, C.M.; Kadish, I.; Thibault, O.; Blalock, E.M.; Porter, N.M.; Landfield, P.W. Disrupting function of FK506-binding protein 1b/12.6 induces the Ca 2+-dysregulation aging phenotype in hippocampal neurons. J. Neurosci. 2011, 31, 1693-1703. [CrossRef]

231. Gant, J.C.; Chen, K.C.; Kadish, I.; Blalock, E.M.; Thibault, O.; Porter, N.M.; Landfield, P.W. Reversal of aging-related neuronal Ca2+ dysregulation and cognitive impairment by delivery of a transgene encoding FK506-binding protein 12.6/1b to the hippocampus. J. Neurosci. 2015, 35, 10878-10887. [CrossRef] [PubMed]

232. Gant, J.C.; Blalock, E.M.; Chen, K.C.; Kadish, I.; Thibault, O.; Porter, N.M.; Landfield, P.W. FK506-binding protein 12.6/1b, a negative regulator of [Ca $2+]$, rescues memory and restores genomic regulation in the hippocampus of aging rats. J. Neurosci. 2018, 38, 1030-1041. [CrossRef] [PubMed]

233. Hersi, M.; Irvine, B.; Gupta, P.; Gomes, J.; Birkett, N.; Krewski, D. Risk factors associated with the onset and progression of Alzheimer's disease: A systematic review of the evidence. Neurotoxicology 2017, 61, 143-187. [CrossRef]

234. Shi, J.; Qian, W.; Yin, X.; Iqbal, K.; Grundke-Iqbal, I.; Gu, X.; Ding, F.; Gong, C.X.; Liu, F. Cyclic AMP-dependent protein kinase regulates the alternative splicing of tau exon 10: A mechanism involved in tau pathology of Alzheimer disease. J. Biol. Chem. 2011, 286, 14639-14648. [CrossRef]

235. Vanderweyde, T.; Apicco, D.J.; Youmans-Kidder, K.; Ash, P.E.A.; Cook, C.; Lummertz da Rocha, E.; Jansen-West, K.; Frame, A.A.; Citro, A.; Leszyk, J.D.; et al. Interaction of tau with the RNA-Binding Protein TIA1 Regulates tau Pathophysiology and Toxicity. Cell Rep. 2016, 15, 1455-1466. [CrossRef]

236. Guo, T.; Noble, W.; Hanger, D.P. Roles of tau protein in health and disease. Acta Neuropathol. 2017, 133, 665-704. [CrossRef]

237. Myeku, N.; Clelland, C.L.; Emrani, S.; Kukushkin, N.V.; Yu, W.H.; Goldberg, A.L.; Duff, K.E. Tau-driven 26S proteasome impairment and cognitive dysfunction can be prevented early in disease by activating cAMP-PKA signaling. Nat. Med. 2016, 22, 46-53. [CrossRef]

238. Lokireddy, S.; Kukushkin, N.V.; Goldberg, A.L. cAMP-induced phosphorylation of 26S proteasomes on Rpn6/PSMD11 enhances their activity and the degradation of misfolded proteins. Proc. Natl. Acad. Sci. USA 2015, 112, E7176-E7185. [CrossRef] [PubMed]

239. Saura, C.A.; Valero, J. The role of CREB signaling in Alzheimer's disease and other cognitive disorders. Rev. Neurosci. 2011, 22, 153-169. [CrossRef]

240. Wen, A.Y.; Sakamoto, K.M.; Miller, L.S. The Role of the Transcription Factor CREB in Immune Function. J. Immunol. 2010, 185, 6413-6419. [CrossRef] [PubMed]

241. Ollivier, V.; Parry, G.C.N.; Cobb, R.R.; De Prost, D.; Mackman, N. Elevated cyclic AMP inhibits NF-кB-mediated transcription in human monocytic cells and endothelial cells. J. Biol. Chem. 1996, 271, 20828-20835. [CrossRef]

242. Role of Cyclic AMP Response Element-Binding Protein in Cyclic AMP Inhibition of NF-Kappab-Mediated TranscriptionPubMed. Available online: https:/ / pubmed.ncbi.nlm.nih.gov/9548485/ (accessed on 28 December 2020).

243. Yamamoto-Sasaki, M.; Ozawa, H.; Saito, T.; Rösler, M.; Riederer, P. Impaired phosphorylation of cyclic AMP response element binding protein in the hippocampus of dementia of the Alzheimer type. Brain Res. 1999, 824, 300-303. [CrossRef]

244. Bartolotti, N.; Bennett, D.A.; Lazarov, O. Reduced pCREB in Alzheimer's disease prefrontal cortex is reflected in peripheral blood mononuclear cells. Mol. Psychiatry 2016, 21, 1158-1166. [CrossRef] 
245. Chauhan, N.B.; Siegel, G.J.; Feinstein, D.L. Propentofylline attenuates tau hyperphosphorylation in Alzheimer's Swedish mutant model Tg2576. Neuropharmacology 2005, 48, 93-104. [CrossRef] [PubMed]

246. Rother, M.; Erkinjuntti, T.; Roessner, M.; Kittner, B.; Marcusson, J.; Karlsson, I. Propentofylline in the treatment of Alzheimer's disease and vascular dementia: A review of phase III trials. Dement. Geriatr. Cogn. Disord. 1998, 9, 36-43. [CrossRef]

247. García-Osta, A.; Cuadrado-Tejedor, M.; García-Barroso, C.; Oyarzábal, J.; Franco, R. Phosphodiesterases as therapeutic targets for Alzheimer's disease. ACS Chem. Neurosci. 2012, 3, 832-844. [CrossRef] [PubMed]

248. Prickaerts, J.; Heckman, P.R.A.; Blokland, A. Investigational phosphodiesterase inhibitors in phase I and phase II clinical trials for Alzheimer's disease. Expert Opin. Investig. Drugs 2017, 26, 1033-1048. [CrossRef]

249. Soares, L.M.; De Vry, J.; Steinbusch, H.W.M.; Milani, H.; Prickaerts, J.; Weffort de Oliveira, R.M. Rolipram improves cognition, reduces anxiety- and despair-like behaviors and impacts hippocampal neuroplasticity after transient global cerebral ischemia. Neuroscience 2016, 326, 69-83. [CrossRef]

250. Paintlia, A.S.; Paintlia, M.K.; Singh, I.; Skoff, R.B.; Singh, A.K. Combination therapy of lovastatin and rolipram provides neuroprotection and promotes neurorepair in inflammatory demyelination model of multiple sclerosis. Glia 2009, 57, 182-193. [CrossRef] [PubMed]

251. Paes, D.; Lardenoije, R.; Carollo, R.M.; Roubroeks, J.A.Y.; Schepers, M.; Coleman, P.; Mastroeni, D.; Delvaux, E.; Pishva, E.; Lunnon, K.; et al. Increased isoform-specific phosphodiesterase 4D expression is associated with pathology and cognitive impairment in Alzheimer's disease. Neurobiol. Aging 2021, 97, 56-64. [CrossRef] [PubMed]

252. Park, S.J.; Ahmad, F.; Philp, A.; Baar, K.; Williams, T.; Luo, H.; Ke, H.; Rehmann, H.; Taussig, R.; Brown, A.L.; et al. Resveratrol ameliorates aging-related metabolic phenotypes by inhibiting cAMP phosphodiesterases. Cell 2012, 148, 421-433. [CrossRef] [PubMed]

253. Wan, D.; Zhou, Y.; Wang, K.; Hou, Y.; Hou, R.; Ye, X. Resveratrol provides neuroprotection by inhibiting phosphodiesterases and regulating the cAMP/AMPK/SIRT1 pathway after stroke in rats. Brain Res. Bull. 2016, 121, 255-262. [CrossRef] [PubMed]

254. Liu, X.; Betzenhauser, M.J.; Reiken, S.; Meli, A.C.; Xie, W.; Chen, B.X.; Arancio, O.; Marks, A.R. Role of leaky neuronal ryanodine receptors in stress- induced cognitive dysfunction. Cell 2012, 150, 1055-1067. [CrossRef]

255. Lacampagne, A.; Liu, X.; Reiken, S.; Bussiere, R.; Meli, A.C.; Lauritzen, I.; Teich, A.F.; Zalk, R.; Saint, N.; Arancio, O.; et al Post-translational remodeling of ryanodine receptor induces calcium leak leading to Alzheimer's disease-like pathologies and cognitive deficits. Acta Neuropathol. 2017, 134, 749-767. [CrossRef] [PubMed]

256. Tibbo, A.J.; Tejeda, G.S.; Baillie, G.S. Understanding PDE4's function in Alzheimer's disease; A target for novel therapeutic approaches. Biochem. Soc. Trans. 2019, 47, 1557-1565. [CrossRef]

257. Arnsten, A.F.T.; Datta, D.; Leslie, S.; Yang, S.T.; Wang, M.; Nairn, A.C. Alzheimer's-like pathology in aging rhesus macaques: Unique opportunity to study the etiology and treatment of Alzheimer's disease. Proc. Natl. Acad. Sci. USA 2019, 116, 26230-26238. [CrossRef]

258. Hermann, D.; Both, M.; Ebert, U.; Gross, G.; Schoemaker, H.; Draguhn, A.; Wicke, K.; Nimmrich, V. Synaptic transmission is impaired prior to plaque formation in amyloid precursor protein-overexpressing mice without altering behaviorally-correlated sharp wave-ripple complexes. Neuroscience 2009, 162, 1081-1090. [CrossRef]

259. Agostinho, P.; Lopes, J.P.; Velez, Z.; Oliveira, C.R. Overactivation of calcineurin induced by amyloid-beta and prion proteins. Neurochem. Int. 2008, 52, 1226-1233. [CrossRef]

260. Chen, Q.S.; Wei, W.Z.; Shimahara, T.; Xie, C.W. Alzheimer amyloid $\beta$-peptide inhibits the late phase of long-term potentiation through calcineurin-dependent mechanisms in the hippocampal dentate gyrus. Neurobiol. Learn. Mem. 2002, 77, 354-371. [CrossRef] [PubMed]

261. Agostinho, P.; Oliveira, C.R. Involvement of calcineurin in the neurotoxic effects induced by amyloid-beta and prion peptides. Eur. J. Neurosci. 2003, 17, 1189-1196. [CrossRef]

262. Dineley, K.T.; Hogan, D.; Zhang, W.R.; Taglialatela, G. Acute inhibition of calcineurin restores associative learning and memory in Tg2576 APP transgenic mice. Neurobiol. Learn. Mem. 2007, 88, 217-224. [CrossRef]

263. Li, H.; Pink, M.D.; Murphy, J.G.; Stein, A.; Dell'Acqua, M.L.; Hogan, P.G. Balanced interactions of calcineurin with AKAP79 regulate Ca 2+-calcineurin-NFAT signaling. Nat. Struct. Mol. Biol. 2012, 19, 337-345. [CrossRef] [PubMed]

264. Hopp, S.C.; Bihlmeyer, N.A.; Corradi, J.P.; Vanderburg, C.; Cacace, A.M.; Das, S.; Clark, T.W.; Betensky, R.A.; Hyman, B.T.; Hudry, E. Neuronal calcineurin transcriptional targets parallel changes observed in Alzheimer disease brain. J. Neurochem. 2018, 147, 24-39. [CrossRef]

265. Braak, H.; Zetterberg, H.; Del Tredici, K.; Blennow, K. Intraneuronal tau aggregation precedes diffuse plaque deposition, but amyloid- $\beta$ changes occur before increases of tau in cerebrospinal fluid. Acta Neuropathol. 2013, 126, 631-641. [CrossRef] [PubMed]

266. Barthélemy, N.R.; Li, Y.; Joseph-Mathurin, N.; Gordon, B.A.; Hassenstab, J.; Benzinger, T.L.S.; Buckles, V.; Fagan, A.M.; Perrin, R.J.; Goate, A.M.; et al. A soluble phosphorylated tau signature links tau, amyloid and the evolution of stages of dominantly inherited Alzheimer's disease. Nat. Med. 2020, 26, 398-407. [CrossRef]

267. Giannakopoulos, P.; Herrmann, F.R.; Bussière, T.; Bouras, C.; Kövari, E.; Perl, D.P.; Morrison, J.H.; Gold, G.; Hof, P.R. Tangle and neuron numbers, but not amyloid load, predict cognitive status in Alzheimer's disease. Neurology 2003, 60, 1495-1500. [CrossRef]

268. Makin, S. The amyloid hypothesis on trial. Nature 2018, 559, S4-S7. [CrossRef]

269. Van Dyck, C.H. Anti-Amyloid- $\beta$ Monoclonal Antibodies for Alzheimer's Disease: Pitfalls and Promise. Biol. Psychiatry 2018, 83, 311-319. [CrossRef] 
270. Mietelska-Porowska, A.; Wasik, U.; Goras, M.; Filipek, A.; Niewiadomska, G. Tau protein modifications and interactions: Their role in function and dysfunction. Int. J. Mol. Sci. 2014, 15, 4671-4713. [CrossRef] [PubMed]

271. Wang, M.; Gamo, N.J.; Yang, Y.; Jin, L.E.; Wang, X.J.; Laubach, M.; Mazer, J.A.; Lee, D.; Arnsten, A.F.T. Neuronal basis of age-related working memory decline. Nature 2011, 476, 210-213. [CrossRef]

272. Jicha, G.A.; Weaver, C.; Lane, E.; Vianna, C.; Kress, Y.; Rockwood, J.; Davies, P. cAMP-dependent protein kinase phosphorylations on Tau in Alzheimer's disease. J. Neurosci. 1999, 19, 7486-7494. [CrossRef] [PubMed]

273. Cao, L.L.; Guan, P.P.; Liang, Y.Y.; Huang, X.S.; Wang, P. Calcium ions stimulate the hyperphosphorylation of tau by activating microsomal prostaglandin E synthase 1. Front. Aging Neurosci. 2019, 11, 108. [CrossRef]

274. Jin, N.; Yin, X.; Yu, D.; Cao, M.; Gong, C.X.; Iqbal, K.; Ding, F.; Gu, X.; Liu, F. Truncation and activation of GSK-3 $\beta$ by calpain I: A molecular mechanism links to tau hyperphosphorylation in Alzheimer's disease. Sci. Rep. 2015, 5, 1-13. [CrossRef]

275. Hundsrucker, C.; Skroblin, P.; Christian, F.; Zenn, H.M.; Popara, V.; Joshi, M.; Eichhorst, J.; Wiesner, B.; Herberg, F.W.; Reif, B.; et al. Glycogen synthase kinase $3 \beta$ interaction protein functions as an a-kinase anchoring protein. J. Biol. Chem. 2010, 285, 5507-5521. [CrossRef]

276. Ko, H.J.; Chiou, S.J.; Wong, Y.H.; Wang, Y.H.; Lai, Y.L.; Chou, C.H.; Wang, C.; Loh, J.K.; Lieu, A.S.; Cheng, J.T.; et al. GSKIPMediated Anchoring Increases Phosphorylation of Tau by PKA but Not by GSK3beta via cAMP/PKA/GSKIP/GSK3/Tau Axis Signaling in Cerebrospinal Fluid and iPS Cells in Alzheimer Disease. J. Clin. Med. 2019, 8, 1751. [CrossRef]

277. Miao, J.; Shi, R.; Li, L.; Chen, F.; Zhou, Y.; Tung, Y.C.; Hu, W.; Gong, C.-X.; Iqbal, K.; Liu, F. Pathological Tau From Alzheimer's Brain Induces Site-Specific Hyperphosphorylation and SDS- and Reducing Agent-Resistant Aggregation of Tau in vivo. Front. Aging Neurosci. 2019, 11, 34. [CrossRef] [PubMed]

278. Mi, K.; Johnson, G. The Role of Tau Phosphorylation in the Pathogenesis of Alzheimers Disease. Curr. Alzheimer Res. 2006, 3 , 449-463. [CrossRef]

279. Sengupta, A.; Kabat, J.; Novak, M.; Wu, Q.; Grundke-Iqbal, I.; Iqbal, K. Phosphorylation of tau at both Thr 231 and Ser 262 is required for maximal inhibition of its binding to microtubules. Arch. Biochem. Biophys. 1998, 357, 299-309. [CrossRef]

280. Augustinack, J.C.; Schneider, A.; Mandelkow, E.M.; Hyman, B.T. Specific tau phosphorylation sites correlate with severity of neuronal cytopathology in Alzheimer's disease. Acta Neuropathol. 2002, 103, 26-35. [CrossRef]

281. Azorsa, D.O.; Robeson, R.L.H.; Frost, D.; Meec Hoovet, B.; Brautigam, G.R.; Dickey, C.; Beaudry, C.; Basu, G.D.; Holz, D.R.; Hernandez, J.A.; et al. High-content siRNA screening of the kinome identifies kinases involved in Alzheimer's disease-related tau hyperphosphorylation. BMC Genomics 2010, 11, 1-10. [CrossRef] [PubMed]

282. Liu, M.; Sui, D.; Dexheimer, T.; Hovde, S.; Deng, X.; Wang, K.W.; Lin, H.L.; Chien, H.T.; Kweon, H.K.; Kuo, N.S.; et al. Hyperphosphorylation Renders Tau Prone to Aggregate and to Cause Cell Death. Mol. Neurobiol. 2020, 57, 4704-4719. [CrossRef] [PubMed]

283. Yang, S.T.; Wang, M.; Paspalas, C.D.; Crimins, J.L.; Altman, M.T.; Mazer, J.A.; Arnsten, A.F.T. Core differences in synaptic signaling between primary visual and dorsolateral prefrontal cortex. Cereb. Cortex 2018, 28, 1458-1471. [CrossRef]

284. Paul, S.; Connor, J.A. NR2B-NMDA receptor-mediated increases in intracellular Ca2+ concentration regulate the tyrosine phosphatase, STEP, and ERK MAP kinase signaling. J. Neurochem. 2010, 114, 1107-1118. [CrossRef] [PubMed]

285. Arnsten, A.F.T.; Wang, M.J.; Paspalas, C.D. Neuromodulation of Thought: Flexibilities and Vulnerabilities in Prefrontal Cortical Network Synapses. Neuron 2012, 76, 223-239. [CrossRef] [PubMed]

286. Johansson, L.; Guo, X.; Hällström, T.; Norton, M.C.; Waern, M.; Östling, S.; Bengtsson, C.; Skoog, I. Common psychosocial stressors in middle-aged women related to longstanding distress and increased risk of Alzheimer's disease: A 38-year longitudinal population study. BMJ Open 2013, 3. [CrossRef]

287. Flatt, J.D.; Gilsanz, P.; Quesenberry, C.P.; Albers, K.B.; Whitmer, R.A. Post-traumatic stress disorder and risk of dementia among members of a health care delivery system. Alzheimer's Dement. 2018, 14, 28-34. [CrossRef]

288. Bale, T.L.; Epperson, C.N. Sex differences and stress across the lifespan. Nat. Neurosci. 2015, 18, 1413-1420. [CrossRef]

289. Fisher, D.W.; Bennett, D.A.; Dong, H. Sexual dimorphism in predisposition to Alzheimer's disease. Neurobiol. Aging 2018, 70, 308-324. [CrossRef]

290. Galla, L.; Redolfi, N.; Pozzan, T.; Pizzo, P.; Greotti, E. Intracellular calcium dysregulation by the alzheimer's disease-linked protein presenilin 2. Int. J. Mol. Sci. 2020, 21, 770. [CrossRef]

291. Gibson, G.; Cotman, C.; Lynch, G.; Blass, J. Calcium Hypothesis of Alzheimer's disease and brain aging: A framework for integrating new evidence into a comprehensive theory of pathogenesis. Alzheimer's Dement. 2017, 13, 178-182.e17. [CrossRef]

292. Tong, B.C.K.; Wu, A.J.; Li, M.; Cheung, K.H. Calcium signaling in Alzheimer's disease \& therapies. Biochim. Biophys. Acta Mol. Cell Res. 2018, 1865, 1745-1760. [PubMed]

293. LaFerla, F.M. Calcium dyshomeostasis and intracellular signalling in alzheimer's disease. Nat. Rev. Neurosci. $2002,3,862-872$. [CrossRef]

294. Kuchibhotla, K.V.; Goldman, S.T.; Lattarulo, C.R.; Wu, H.; Bradley, T.; Bacskai, B.J. Abeta plaques lead to aberrant regulation of calcium homeostasis in vivo resulting in structural and functional disruption of neuronal networks. Neuron 2008, 59, $214-225$. [CrossRef]

295. Brawek, B.; Garaschuk, O. Network-wide dysregulation of calcium homeostasis in Alzheimer's disease. Cell Tissue Res. 2014, 357, 427-438. [CrossRef] 
296. Popugaeva, E.; Pchitskaya, E.; Bezprozvanny, I. Dysregulation of neuronal calcium homeostasis in Alzheimer's disease-A therapeutic opportunity? Biochem. Biophys. Res. Commun. 2017, 483, 998-1004. [CrossRef]

297. Toglia, P.; Cheung, K.H.; Mak, D.O.D.; Ullah, G. Impaired mitochondrial function due to familial Alzheimer's disease-causing presenilins mutants via Ca2+ disruptions. Cell Calcium 2016, 59, 240-250. [CrossRef]

298. Tu, H.; Nelson, O.; Bezprozvanny, A.; Wang, Z.; Lee, S.F.; Hao, Y.H.; Serneels, L.; De Strooper, B.; Yu, G.; Bezprozvanny, I. Presenilins Form ER Ca2+ Leak Channels, a Function Disrupted by Familial Alzheimer's Disease-Linked Mutations. Cell 2006, 126, 981-993. [CrossRef] [PubMed]

299. Wu, B.; Yamaguchi, H.; Lai, F.A.; Shen, J. Presenilins regulate calcium homeostasis and presynaptic function via ryanodine receptors in hippocampal neurons. Proc. Natl. Acad. Sci. USA 2013, 110, 15091-15096. [CrossRef]

300. Bruno, A.M.; Huang, J.Y.; Bennett, D.A.; Marr, R.A.; Hastings, M.L.; Stutzmann, G.E. Altered ryanodine receptor expression in mild cognitive impairment and Alzheimer's disease. Neurobiol. Aging 2012, 33, 1001.e1.-1001.e6. [CrossRef]

301. Wang, X.; Zheng, W. Ca2+ homeostasis dysregulation in Alzheimer's disease: A focus on plasma membrane and cell organelles. FASEB J. 2019, 33, 6697-6712. [CrossRef] [PubMed]

302. Calvo-Rodriguez, M.; Hou, S.S.; Snyder, A.C.; Kharitonova, E.K.; Russ, A.N.; Das, S.; Fan, Z.; Muzikansky, A.; Garcia-Alloza, M.; Serrano-Pozo, A.; et al. Increased mitochondrial calcium levels associated with neuronal death in a mouse model of Alzheimer's disease. Nat. Commun. 2020, 11, 2146. [CrossRef] [PubMed]

303. Jadiya, P.; Kolmetzky, D.W.; Tomar, D.; Di Meco, A.; Lombardi, A.A.; Lambert, J.P.; Luongo, T.S.; Ludtmann, M.H.; Praticò, D.; Elrod, J.W. Impaired mitochondrial calcium efflux contributes to disease progression in models of Alzheimer's disease. Nat. Commun. 2019, 10, 1-14. [CrossRef] [PubMed]

304. Lees, A.J.; Hardy, J.; Revesz, T. Parkinson's disease. Lancet 2009, 373, 2055-2066. [CrossRef]

305. Xie, Z.; Adamowicz, W.O.; Eldred, W.D.; Jakowski, A.B.; Kleiman, R.J.; Morton, D.G.; Stephenson, D.T.; Strick, C.A.; Williams, R.D.; Menniti, F.S. Cellular and subcellular localization of PDE10A, a striatum-enriched phosphodiesterase. Neuroscience 2006, 139, 597-607. [CrossRef]

306. Lakics, V.; Karran, E.H.; Boess, F.G. Quantitative comparison of phosphodiesterase mRNA distribution in human brain and peripheral tissues. Neuropharmacology 2010, 59, 367-374. [CrossRef] [PubMed]

307. Niccolini, F.; Foltynie, T.; Reis Marques, T.; Muhlert, N.; Tziortzi, A.C.; Searle, G.E.; Natesan, S.; Kapur, S.; Rabiner, E.A.; Gunn, R.N.; et al. Loss of phosphodiesterase 10A expression is associated with progression and severity in Parkinson's disease. Brain 2015, 138, 3003-3015. [CrossRef] [PubMed]

308. Lee, Y.Y.; Park, J.S.; Leem, Y.H.; Park, J.E.; Kim, D.Y.; Choi, Y.H.; Park, E.M.; Kang, J.L.; Kim, H.S. The phosphodiesterase 10 inhibitor papaverine exerts anti-inflammatory and neuroprotective effects via the PKA signaling pathway in neuroinflammation and Parkinson's disease mouse models. J. Neuroinflamm. 2019, 16, 1-17. [CrossRef]

309. Mossman, J.A.; Biancani, L.M.; Rand, D.M. Mitochondrial genomic variation drives differential nuclear gene expression in discrete regions of Drosophila gene and protein interaction networks. BMC Genomics 2019, 20, 1-23. [CrossRef]

310. Giampà, C.; Laurenti, D.; Anzilotti, S.; Bernardi, G.; Menniti, F.S.; Fusco, F.R. Inhibition of the striatal specific phosphodiesterase PDE10A ameliorates striatal and cortical pathology in R6/2 mouse model of Huntington's disease. PLoS ONE 2010, 5, e13417. [CrossRef]

311. Nthenge-Ngumbau, D.N.; Mohanakumar, K.P. Can Cyclic Nucleotide Phosphodiesterase Inhibitors Be Drugs for Parkinson's Disease? Mol. Neurobiol. 2018, 55, 822-834. [CrossRef]

312. Diggle, C.P.; Sukoff Rizzo, S.J.; Popiolek, M.; Hinttala, R.; Schülke, J.P.; Kurian, M.A.; Carr, I.M.; Markham, A.F.; Bonthron, D.T.; Watson, C.; et al. Biallelic Mutations in PDE10A Lead to Loss of Striatal PDE10A and a Hyperkinetic Movement Disorder with Onset in Infancy. Am. J. Hum. Genet. 2016, 98, 735-743. [CrossRef] [PubMed]

313. Chen, D.H.; Méneret, A.; Friedman, J.R.; Korvatska, O.; Gad, A.; Bonkowski, E.S.; Stessman, H.A.; Doummar, D.; Mignot, C.; Anheim, M.; et al. ADCY5-related dyskinesia: Broader spectrum and genotype-phenotype correlations. Neurology 2015, 85, 2026-2035. [CrossRef]

314. Chen, Y.Z.; Friedman, J.R.; Chen, D.H.; Chan, G.C.K.; Bloss, C.S.; Hisama, F.M.; Topol, S.E.; Carson, A.R.; Pham, P.H.; Bonkowski, E.S.; et al. Gain-of-function ADCY5 mutations in familial dyskinesia with facial myokymia. Ann. Neurol. 2014, 75, 542-549. [CrossRef] [PubMed]

315. Park, H.Y.; Kang, Y.M.; Kang, Y.; Park, T.S.; Ryu, Y.K.; Hwang, J.H.; Kim, Y.H.; Chung, B.H.; Nam, K.H.; Kim, M.R.; et al. Inhibition of adenylyl cyclase type 5 prevents L-DOPA-induced dyskinesia in an animal model of Parkinson's disease. J. Neurosci. 2014, 34, 11744-11753. [CrossRef] [PubMed]

316. Nagai, T.; Yoshimoto, J.; Kannon, T.; Kuroda, K.; Kaibuchi, K. Phosphorylation Signals in Striatal Medium Spiny Neurons. Trends Pharmacol. Sci. 2016, 37, 858-871. [CrossRef]

317. Snyder, G.L.; Fienberg, A.A.; Huganir, R.L.; Greengard, P. A dopamine/D1 receptor/protein kinase A/dopamine- and cAMPregulated phosphoprotein $(\mathrm{M}(\mathrm{r}) 32 \mathrm{kDa})$ / protein phosphatase-1 pathway regulates dephosphorylation of the NMDA receptor. J. Neurosci. 1998, 18, 10297-10303. [CrossRef]

318. Parisiadou, L.; Yu, J.; Sgobio, C.; Xie, C.; Liu, G.; Sun, L.; Gu, X.L.; Lin, X.; Crowley, N.A.; Lovinger, D.M.; et al. LRRK2 regulates synaptogenesis and dopamine receptor activation through modulation of PKA activity. Nat. Neurosci. 2014, 17, 367-376. [CrossRef] 
319. Gandhi, P.N.; Chen, S.G.; Wilson-Delfosse, A.L. Leucine-rich repeat kinase 2 (LRRK2): A key player in the pathogenesis of Parkinson's disease. J. Neurosci. Res. 2009, 87, 1283-1295. [CrossRef] [PubMed]

320. Taylor, M.; Alessi, D.R. Advances in elucidating the function of leucine-rich repeat protein kinase-2 in normal cells and Parkinson's disease. Curr. Opin. Cell Biol. 2020, 63, 102-113. [CrossRef]

321. Oliveira, R.F.; Kim, M.; Blackwell, K.T. Subcellular location of PKA controls striatal plasticity: Stochastic simulations in spiny dendrites. PLoS Comput. Biol. 2012, 8. [CrossRef] [PubMed]

322. Zhong, H.; Sia, G.M.; Sato, T.R.; Gray, N.W.; Mao, T.; Khuchua, Z.; Huganir, R.L.; Svoboda, K. Subcellular Dynamics of Type II PKA in Neurons. Neuron 2009, 62, 363-374. [CrossRef] [PubMed]

323. Giesert, F.; Glasl, L.; Zimprich, A.; Ernst, L.; Piccoli, G.; Stautner, C.; Zerle, J.; Hölter, S.M.; Vogt Weisenhorn, D.M.; Wurst, W. The pathogenic LRRK2 R1441C mutation induces specific deficits modeling the prodromal phase of Parkinson's disease in the mouse. Neurobiol. Dis. 2017, 105, 179-193. [CrossRef]

324. Yasuda, H.; Barth, A.L.; Stellwagen, D.; Malenka, R.C. A developmental switch in the signaling cascades for LTP induction. Nat. Neurosci. 2003, 6, 15-16. [CrossRef] [PubMed]

325. Zaja-Milatovic, S.; Milatovic, D.; Schantz, A.M.; Zhang, J.; Montine, K.S.; Samii, A.; Deutch, A.Y.; Montine, T.J. Dendritic degeneration in neostriatal medium spiny neurons in Parkinson disease. Neurology 2005, 64, 545-547. [CrossRef] [PubMed]

326. Dächsel, J.C.; Taylor, J.P.; Mok, S.S.; Ross, O.A.; Hinkle, K.M.; Bailey, R.M.; Hines, J.H.; Szutu, J.; Madden, B.; Petrucelli, L.; et al. Identification of potential protein interactors of Lrrk2. Park. Relat. Disord. 2007, 13, 382-385. [CrossRef]

327. Tozzi, A.; Tantucci, M.; Marchi, S.; Mazzocchetti, P.; Morari, M.; Pinton, P.; Mancini, A.; Calabresi, P. Dopamine D2 receptormediated neuroprotection in a G2019S Lrrk2 genetic model of Parkinson's disease. Cell Death Dis. 2018, 9. [CrossRef] [PubMed]

328. Ramonet, D.; Daher, J.P.L.; Lin, B.M.; Stafa, K.; Kim, J.; Banerjee, R.; Westerlund, M.; Pletnikova, O.; Glauser, L.; Yang, L.; et al. Dopaminergic Neuronal loss, Reduced Neurite Complexity and Autophagic Abnormalities in Transgenic Mice Expressing G2019S Mutant LRRK2. PLoS ONE 2011, 6, e18568. [CrossRef]

329. Cherra, S.J.; Kulich, S.M.; Uechi, G.; Balasubramani, M.; Mountzouris, J.; Day, B.W.; Chu, C.T. Regulation of the autophagy protein LC3 by phosphorylation. J. Cell Biol. 2010, 190, 533-539. [CrossRef] [PubMed]

330. Giacomello, M.; Pyakurel, A.; Glytsou, C.; Scorrano, L. The cell biology of mitochondrial membrane dynamics. Nat. Rev. Mol. Cell Biol. 2020, 21, 204-224. [CrossRef]

331. Lee, H.; Yoon, Y. Mitochondrial fission and fusion. Biochem. Soc. Trans. 2016, 44, 1725-1735. [CrossRef] [PubMed]

332. Chang, C.-R.; Blackstone, C. Cyclic AMP-dependent protein kinase phosphorylation of Drp1 regulates its GTPase activity and mitochondrial morphology. J. Biol. Chem. 2007, 282, 21583-21587. [CrossRef] [PubMed]

333. Cereghetti, G.M.; Stangherlin, A.; de Brito, O.M.; Chang, C.R.; Blackstone, C.; Bernardi, P.; Scorrano, L. Dephosphorylation by calcineurin regulates translocation of Drp1 to mitochondria. Proc. Natl. Acad. Sci. USA 2008, 105, 15803-15808. [CrossRef] [PubMed]

334. Zhang, J.; Feng, J.; Ma, D.; Wang, F.; Wang, Y.; Li, C.; Wang, X.; Yin, X.; Zhang, M.; Dagda, R.K.; et al. Neuroprotective Mitochondrial Remodeling by AKAP121/PKA Protects HT22 Cell from Glutamate-Induced Oxidative Stress. Mol. Neurobiol. 2019, 56, 5586-5607. [CrossRef]

335. Venkataraman, K.; Khurana, S.; Tai, T.C. Oxidative stress in aging-matters of the heart and mind. Int. J. Mol. Sci. 2013, 14, 17897-17925. [CrossRef]

336. Surmeier, D.J.; Schumacker, P.T.; Guzman, J.D.; Ilijic, E.; Yang, B.; Zampese, E. Calcium and Parkinson's disease. Biochem. Biophys. Res. Commun. 2017, 483, 1013-1019. [CrossRef]

337. Ludtmann, M.H.R.; Abramov, A.Y. Mitochondrial calcium imbalance in Parkinson's disease. Neurosci. Lett. 2018, 663, 86-90. [CrossRef]

338. Post, M.R.; Lieberman, O.J.; Mosharov, E.V. Can interactions between $\alpha$-synuclein, dopamine and calcium explain selective neurodegeneration in Parkinson's disease? Front. Neurosci. 2018, 12, 1-11. [CrossRef] [PubMed]

339. Gandhi, S.; Wood-Kaczmar, A.; Yao, Z.; Plun-Favreau, H.; Deas, E.; Klupsch, K.; Downward, J.; Latchman, D.S.; Tabrizi, S.J.; Wood, N.W.; et al. PINK1-Associated Parkinson's Disease Is Caused by Neuronal Vulnerability to Calcium-Induced Cell Death. Mol. Cell 2009, 33, 627-638. [CrossRef]

340. Huang, E.; Qu, D.; Huang, T.; Rizzi, N.; Boonying, W.; Krolak, D.; Ciana, P.; Woulfe, J.; Klein, C.; Slack, R.S.; et al. PINK1-mediated phosphorylation of LETM1 regulates mitochondrial calcium transport and protects neurons against mitochondrial stress. Nat. Commun. 2017, 8, 1-11. [CrossRef] [PubMed]

341. Soman, S.; Keatinge, M.; Moein, M.; Da Costa, M.; Mortiboys, H.; Skupin, A.; Sugunan, S.; Bazala, M.; Kuznicki, J.; Bandmann, O. Inhibition of the mitochondrial calcium uniporter rescues dopaminergic neurons in pink1-/- zebrafish. Eur. J. Neurosci. 2017, 45, 528-535. [CrossRef] [PubMed]

342. Soman, S.K.; Bazała, M.; Keatinge, M.; Bandmann, O.; Kuznicki, J. Restriction of mitochondrial calcium overload by mcu inactivation renders a neuroprotective effect in zebrafish models of Parkinson's disease. Biol. Open 2019, 8. [CrossRef] [PubMed]

343. Liu, Y.; Ma, X.; Fujioka, H.; Liu, J.; Chen, S.; Zhu, X. DJ-1 regulates the integrity and function of ER-mitochondria association through interaction with IP3R3-Grp75-VDAC1. Proc. Natl. Acad. Sci. USA 2019, 116, 25322-25328. [CrossRef]

344. Ottolini, D.; Calì, T.; Negro, A.; Brini, M. The Parkinson disease-related protein DJ-1 counteracts mitochondrial impairment induced by the tumour suppressor protein p53 by enhancing endoplasmic reticulum-mitochondria tethering. Hum. Mol. Genet. 2013, 22, 2152-2168. [CrossRef] [PubMed] 
345. Wang, Y.; Shi, Y.; Wei, H. Calcium Dysregulation in Alzheimer's Disease: A Target for New Drug Development. J. Alzheimer's Dis. Park. 2017. [CrossRef]

346. Lovell, M.A.; Abner, E.; Kryscio, R.; Xu, L.; Fister, S.X.; Lynn, B.C. Calcium Channel Blockers, Progression to Dementia, and Effects on Amyloid Beta Peptide Production. Oxid. Med. Cell. Longev. 2015, 2015, 787805. [CrossRef]

347. Tadic, V.; Prell, T.; Lautenschlaeger, J.; Grosskreutz, J. The ER mitochondria calcium cycle and ER stress response as therapeutic targets in amyotrophic lateral sclerosis. Front. Cell. Neurosci. 2014, 8, 1-17. [CrossRef]

348. Jaiswal, M.K. Riluzole but not melatonin ameliorates acute motor neuron degeneration and moderately inhibits sod1-mediated excitotoxicity induced disrupted mitochondrial Ca2+ signaling in amyotrophic lateral sclerosis. Front. Cell. Neurosci. 2017, 10, 1-14. [CrossRef]

349. Cohen, A.A.; Kennedy, B.K.; Anglas, U.; Bronikowski, A.M.; Deelen, J.; Dufour, F.; Ferbeyre, G.; Ferrucci, L.; Franceschi, C.; Frasca, D.; et al. Lack of consensus on an aging biology paradigm? A global survey reveals an agreement to disagree, and the need for an interdisciplinary framework. Mech. Ageing Dev. 2020, 191, 111316. [CrossRef] 